\title{
An Economic Analysis of Transportation Fuel Policies in Brazil: Fuel Choice, Land Use, and Environmental Impacts
}

\section{Introduction}

Brazil has the second largest biofuel industry in the world after the US. The Brazilian biofuel industry was initiated in mid-1970s by a government program, Proalcool, which provided economic incentives to ethanol producers and consumers through price supports and supply guarantees aiming to substitute gasoline with domestically produced sugarcane ethanol. By the end of 1980s, the subsidies and price supports were eliminated and the ethanol industry has been deregulated since then. The conventional transportation fuels market, on the other hand, is administered strictly by the government through taxes, price controls, and blending mandates to achieve market stability, make ethanol competitive with gasoline, and avoid adverse effects of volatile fuel prices on other sectors of the economy. Despite all the stabilization efforts, the transportation fuels sector has been quite dynamic in recent years. In Brazil, the ethanol and sugar markets are strongly related since sugarcane is the common feedstock for producing ethanol and sugar. Sugar production has increased hand in hand with ethanol expansion reaching 38 million tons in 2012/2013 (UNICA, 2013). In the past decade, the global sugar markets also have been quite dynamic. The strong sugar demand and rising prices observed until 2011 are replaced by a significant oversupply and declining prices in recent years (Figure 1). This has had an important impact on the Brazil sugar industry, thus the ethanol sector. Sugar is one of Brazil's main export products in which it exerts a world market power; therefore, the price of sugar drives the sugarcane price together with the price of ethanol. Since the deregulation of the ethanol market, the two prices move together (Serra et al., 2010).

In the past four decades, Brazil has implemented a mandate for blending anhydrous ethanol into gasoline where the blending ratio varied in the range of $4.5 \%-27 \%$. The blended fuel (gasoline + anhydrous ethanol, called 'gasohol') is consumed by both conventional passenger 
vehicles $(\mathrm{CV})$ and flex-fuel vehicles (FFV). The FFV category, along with ethanol-dedicated vehicles (EDV), can also run on pure ethanol (E100). Hence, FFV drivers have the flexibility to move between gasohol and E100 depending on their relative prices. Because of this flexibility, the FFV fleet expanded steadily since the Brazilian automotive industry introduced FFVs into the market in 2003. By 2010, one third of the light vehicle stock was comprised by flex-fuel vehicles and approximately $50 \%$ of the light duty vehicle-miles were driven by FFVs (Salvo and Huse, 2013). DENATRAN (2015) reports that the flex-fuel automotive fleet in the country increased $34 \%$ in the last two years. This raised the share of FFVs in the entire light duty vehicle fleet to $68 \%$, which is expected to go up further to $86 \%$ in $2020 .{ }^{1}$ The transportation fuels distribution infrastructure is developed accordingly and geared towards the use of gasohol and pure ethanol that can be consumed by FFVs. According to the Agência Nacional do Petróleo, Gás Natural e Biocombustíveis (ANP, 2013), the domestic total ethanol sales increased by $160 \%$ from 2004 to 2013. Although most of the ethanol consumption has occurred in the Southeast, where São Paulo and the other main ethanol producing states are located, sales have been increased significantly throughout the country during the same period. The flexibility thus acquired by fuel consumers makes the fuel policy critical for all market participants, including both fuel consumers and producers. The sugarcane ethanol producers face a particularly high uncertainty since the Brazil ethanol market is not regulated and competes with sugar production. ${ }^{2}$ The ethanol-blending ratio was set at 25\% during the period 2005-2011. In 2011, in response to the short supply of domestic ethanol, the ethanol blending rate was reduced from $25 \%$ to $20 \%$ In contrast, due to the high sugarcane production and supply of ethanol in 2013 and weaker global sugar markets compared to the pre-2011 conditions, the government increased the blending

\footnotetext{
${ }^{1}$ See UNICA project at http://sugarcane.org/the-brazilian-experience/brazilian-transportation-fleet

${ }^{2}$ It is important to mention that sugarcane mills have limited ability to switch their production line discretionally between sugar and ethanol. Currently, $72 \%$ of the sugarcane mills can produce both sugar and ethanol in a 60/40 proportion. Of the remaining mills, 26\% produce ethanol only and the rest produce sugar only (MAPA, 2012).
} 
mandate back to $25 \%$. To curb the substantial losses from subsidized domestic gasoline sales by refineries, in the past few years the price of gasoline was raised by more than $10 \%$. In 2015, the blending limit was raised further to $27 \%$ to increase the domestic consumption and price of ethanol, thus provide relief to the long stressed ethanol sector. Although the sugarcane area expanded by 30\% during the period 2005-2011, the production of sugarcane and ethanol could not keep up with the growing demand for fuel ethanol. The short supply of ethanol was a result of: 1) the strong global sugar markets which ramped up Brazil's sugar exports (Portal Brasil, 2011a) and reduced the amount of sugarcane crushed for ethanol, and 2) the decline in total recoverable sugar and sugarcane yield (about $10 \%$ and 5\%, respectively) particularly during the period 2007-2010 (MAPA, 2010). Consequently, although historically Brazil has been a net ethanol exporter, the country had to import corn ethanol from the US in recent years to meet the domestic ethanol demand (Figure 2).

Another crucial policy instrument in Brazil is the tax rate on transportation fuels. The taxes applied to gasoline and ethanol, which vary at federal and state levels, are often modified to make E100 competitive with gasohol and to avoid volatility in fuel prices (Portal Brasil, 2011b). Thus, lower federal tax rates $\left(\mathrm{CIDE}^{3}\right)$ and other charges $\left(\mathrm{PIS} / \mathrm{PASEP}^{4}\right.$ and COFINS $\left.{ }^{5}\right)$ are provided to E100 and anhydrous ethanol relative to gasoline. Many states also impose a lower ad-valorem tax rate $\left(\mathrm{ICMS}^{6}\right.$ ) for ethanol (ANP, 2011). Overall, prior to 2011, pure gasoline was taxed slightly more than $100 \%$ while the tax on E100 and anhydrous ethanol was lower than $40 \%$. When the ethanol blending rate was reduced in 2011, simultaneously the CIDE tax rate on gasoline was reduced by $20 \%$ and then by $33 \%$ to protect the domestic fuel consumers and

\footnotetext{
${ }^{3}$ Contribuição de Intervenção no Domínio Econômico (Compulsory contributions for the purpose of achieving economic stability).

${ }^{4}$ Programa de Integração Social (Social Integration Program) and Programa de Formação do Patrimônio do Servidor Público (Civil Service Asset Formation Program).

${ }^{5}$ Contribuição para o Financiamento da Seguridade Social (Contribution for the Financing of Social Security).

${ }^{6}$ Imposto sobre Circulação de Mercadorias e Prestação de Serviços (Tax on the Circulation of Goods and Services).
} 
reduce the inflationary effect of high fuel prices on other sectors of the economy. The federal tax on transportation fuels were eliminated in 2012, but in 2015 it is introduced back (currently gasoline tax is about $7 \%$ of the retail price).

To complete the 'tool box' of the fuel policy instruments, PETROBRAS, the main Brazilian oil refinery and domestic fuel wholesaler which controls more than $90 \%$ of the gasoline market in Brazil (Fecombustíveis, 2011) ${ }^{7}$, regulates the refinery price of gasoline (PETROBRAS, 2011). Figure 3 illustrates the price movements in the Brazilian and international wholesale gasoline markets over the period 2005-2013. Between 2005 and 2011, PETROBRAS has kept the price almost constant and around the average international price, but the domestic price has been significantly lower than the global prices after 2011. In the third quarter of 2012, for instance, the price of gasoline in Brazil was $19 \%$ below the world price although part of the consumption was imported. Importing transportation fuels at higher world prices and selling in the domestic market at subsidized prices resulted in substantial losses that forced PETROBRAS to adopt a market-driven price policy. The company plans to close the gap between the domestic and international fuel prices gradually. As a first step in that direction the price of gasoline was raised twice, first by $6.6 \%$ and then by $4 \%$, in 2013 . Unlike gasoline, the price of ethanol is not regulated and has fluctuated over time depending on the adjustments in the fuel blending ratio and the tax rates determined by the federal and state governments. Despite the tax incentives provided to ethanol consumers, low gasoline prices in recent years weakened the competitiveness of ethanol against gasoline and reduced the share of ethanol in the total fuel consumption (by energy content) from 44\% in 2008 to 30\% in 2013 (Empresa de Pesquisa Energetica, 2013).

While Brazil's ethanol industry has been struggling lately, the US biofuel production has grown at a dramatic rate in the past decade (see Figure 4) primarily due to the blending mandates

${ }^{7}$ The Government of Brazil is the largest stockholder of PETROBRAS. 
imposed by the Renewable Fuel Standard (RFS). This made the US the world's largest ethanol producer since 2007. The RFS aims to increase the amount of biofuels blended with conventional fuels to 136 billion liters by 2022. An important component of this target is the 'advanced' biofuel mandate ${ }^{8}$, which is set as 79 billion liters for 2022. According to the RFS provisions, at least 60 billion liters of this amount must be derived from cellulosic biomass while the rest can be met by biodiesel and sugarcane ethanol. Due to the slow progress in cellulosic biofuel production, a significant part of the undifferentiated advanced biofuel mandate was met by sugarcane ethanol imported from Brazil. If an economically competitive cellulosic biofuel technology cannot be established by 2022 and the RFS is maintained, this trend may continue and meeting the advanced biofuel mandate may require importing as much as 20 billion liters of sugarcane ethanol from Brazil. This corresponds to about one-third of Brazil's projected ethanol production in 2022. Therefore, the RFS advanced biofuel mandate may have important implications not only for the US biofuel sector but for the Brazil ethanol industry as well. ${ }^{9}$

In this paper, we use an economic simulation model to analyze the impacts of the fuel policies discussed above on Brazil's transportation fuel sector, producers' supply responses, consumers' driving demand and fuel choice, ethanol trade with the rest of the world, land use, greenhouse gas (GHG) emissions, and social welfare. In the model, we incorporate the linkages between the domestic and global sugar markets and ethanol markets explicitly to analyze the trade-offs.

\footnotetext{
${ }^{8}$ Advanced biofuels are biofuels that reduce the GHG emissions by at least $50 \%$ relative to the fossil fuels they replace. Sugarcane ethanol, biodiesel, and cellulosic biofuels meet this criterion while corn ethanol does not.

9 A drastic policy change has been proposed by the EPA for the 2014 mandates, which may alter such expectations. For the first time since 2005, besides waiving the cellulosic biofuel target, the 2014 proposal reduces the mandates for both advanced biofuels and corn ethanol. Specifically, the total amount of biofuels blended with fossil fuels is reduced from 68.6 billion liters (the original 2014 mandate) to 57.5 billion liters (16\% reduction), while the advanced biofuel mandate is reduced from 14.1 billion liters to 8.3 billion liters (41\% reduction). Most of the latter is met by biodiesel that leaves less than expected room for Brazilian sugarcane ethanol. This proposal is motivated by the technical limitations in blending ethanol with gasoline (known as the 'blend wall'), less than anticipated fuel consumption, and the absence of economically viable non-ethanol (drop-in) biofuels in the US market.
} 


\section{Research Problem}

The correlation between the fuel and agricultural commodity markets and market volatility described above make the public policy a crucial issue in the Brazilian biofuel economy. We focus on two main policy instruments currently employed by the government, namely the fuel blending rate and gasoline pricing through fuel taxes. We note that our analysis is not a short-run equilibrium analysis. The government uses blending rate as a policy instrument to deal with ethanol supply shortages or surpluses after observing the market conditions, or to transfer income to the ethanol industry when needed. Our model treats the blending mandate and fuel taxes as stable policy choices rather than short run market balancing and price equilibrating mechanisms. These two instruments not only affect the consumer's fuel preference, they are also signals to the ethanol and sugarcane producers indicating the policy maker's vision about the market. The ethanol industry may respond to those signals by shrinking/expanding the processing capacity or crushing more/less sugarcane for ethanol, while farmers may allocate more/less agricultural land to sugarcane. Therefore, the purpose of considering alternative blending rate and tax rate specifications is to investigate the impacts of different fuel policy designs on the domestic fuel markets. As market uncertainties, we consider alternative supply scenarios for sugarcane and alternative global demand scenarios for ethanol and sugar. Consideration of supply uncertainty is motivated by potential climate-related productivity changes and yield declines as sugarcane acreage expands in marginal areas while demand uncertainty is driven largely by biofuel policies, in particular the RFS2's undifferentiated advanced biofuels mandate in the US, which may or may not be implemented in the next decade. If it is maintained and cellulosic ethanol cannot be produced at commercial scale as an economically viable alternative, this would affect the production plans and market equilibria in the Brazilian agriculture and biofuel sectors. In the analysis here, we consider a high versus low 
sugarcane productivity and a strong versus weak demand for both ethanol and sugar in the world markets. These possibilities are coupled to design four scenarios that involve challenging demand and supply conditions that the Brazilian biofuel industry may face over the next decade. Under each of those four scenarios, we investigate the implications of various fuel taxes and blending mandates on: i) the resource allocation in agriculture, ii) the share of ethanol in sugarcane processing, and iii) the mix of transportation fuels consumed by all vehicle categories. We also determine (ex-post) the welfare impacts on Brazilian food and fuel consumers, global GHG emissions, and government revenue/loss.

The present study contributes to the related literature in three aspects. First, it presents a price endogenous economic simulation model of Brazilian agricultural and transportation fuel sectors in a unified framework considering the competition between sugarcane and other major crop products, the competition between sugar and ethanol which use sugarcane as the common feedstock, and the government's fuel policies that drive consumers' driving behavior and fuel choices. Some previous studies have addressed the economic effects of the introduction of flexfuel vehicles in Brazil (e.g., Pacini \& Silveira, 2011; Schmitt, Szklo, \& Schaeffer, 2011; de Freitas \& Kaneko, 2011a, 2011b), but to our knowledge no published study empirically analyzed the impacts of fuel policies on the supply behavior of farmers and ethanol producers, the consumers' driving behavior, fuel substitution, and the amount of fuel consumption by different vehicle categories. The literature on economic analysis and assessment of fuel pricing, blending mandates, and tax policies in Brazil relied on stylized models with a high level of aggregation (e.g., de Gorter et al., 2013; Babcock et al., 2013). The model we use here simulates both the feedstock supply structure and fuel consumption at highly disaggregated levels, specifically at mesoregion and state level, respectively. 


\section{Methods}

As the analytical tool, we use a price endogenous mathematical programming model that was developed earlier by Nuñez et al. (2013) and modified here to address the policy issues described above. For readability, we provide an overview of the model in this section. A detailed mathematical description is presented in the appendix.

The objective function of the model represents the sum of producers' and consumers' surplus (social surplus) derived from the production and consumption of agricultural commodities and transportation fuels by light-duty vehicles that generate vehicle-kilometerstraveled (VKT). Maximization of the social surplus subject to the regional resource limitations, material balance constraints, technical constraints, and policy restrictions determines the equilibrium in agricultural and fuel markets simultaneously (Takayama and Judge, 1971; McCarl and Spreen, 1980). The biofuel policies directly affect the production and utilization of sugarcane, which in turn affects the production of other agricultural commodities competing with sugarcane for agricultural lands. This is particularly the case for corn and soybeans that are among the major commodities exported by Brazil. To incorporate the linkages between the domestic and global markets of these commodities, we develop a similar spatially explicit agricultural sector model for the US and Argentina who are also major exporters of corn and soybeans. In addition to the bilateral trade between these three countries, the food/feed and biofuel markets of the ROW and China are also included in the model by incorporating their explicit excess demand/supply functions. The ethanol import demands of the ROW and China are specified based on the OECD projections for ethanol trade with the European Union (EU, a major importer of Brazilian and US ethanol), Canada and China, which in turn are based on their ethanol blending mandates (Araujo and Lu, 2010; OECD-FAO, 2011) ${ }^{10}$ China also targets a

\footnotetext{
10 The Renewable Energy Directive of the EU targets $10 \%$ renewable fuel content in transportation fuels by 2020. Although the targeted blending rate has been reduced recently by the EU, the model relies on the original $10 \%$
} 
$10 \%$ blending rate for 2020 . We assume that the future ethanol import demands of the EU, Canada, and China will be met by Brazil and the US.

In the Brazil, US, and Argentina components, the supply of primary crops and processed products (including ethanol) is modeled assuming Leontief production functions. The agricultural supply is regionally disaggregated at mesoregion level in the Brazil component, at Crop Reporting District level in the US component, and at province level in the Argentina component.

In the fuel sector, ethanol and gasoline ${ }^{11}$ are assumed to be perfect substitutes within the specified blending regulations to generate VKT. The model assumes an upward sloping supply function for gasoline in the US, ROW and China components while a perfectly elastic supply function is assumed in the Brazil component reflecting the constant pricing policy. Because of the long transportation distances between the potential ethanol production regions and gasoline refineries to the consumption/export locations, a fuel transportation module is included in the Brazil component. Specifically, each state is assigned a VKT demand function for each of the three vehicle types (CV, FFV, and EDV), and the fuels needed to generate the VKT demand in each state are delivered from the ethanol producing mesoregions, gasoline refineries ${ }^{12}$, or ports at least cost. The model determines the optimal supply chain network simultaneously with the food and fuel market equilibrium. ${ }^{13}$

ethanol blending mandate. Five provinces in China already require a $10 \%$ ethanol blending rate. These and other mandates around the world can be found at http://www.biofuelsdigest.com/bdigest/2013/12/31/biofuels-mandatesaround-the-world-2014/

11 These fuels are perfect substitutes (except their energy content) for flex-fuel vehicles in Brazil, but since gasoline is consumed only in blended form (gasohol), the substitution relationship is actually between ethanol and gasohol.

12 There are 13 gasoline refineries located in the mesoregions of Metropolitana de Porto Alegre, Metropolitana de São Paulo, Campinas, Vale do Paraíba Paulista, , Metropolitana do Rio de Janeiro, Centro Amazonense, Metropolitana de Fortaleza, Metropolitana de Belo Horizonte, Metropolitana de Curitiba, Metropolitana de Salvador, Sudeste Rio-grandense.

${ }^{13}$ For mathematical simplicity, we do not give a detailed description of this module in the model appendix. 


\section{Data and Scope of the Model}

The model is calibrated and validated using 2007 as the base year. The data inputs include the food and VKT demand functions, regional crop and livestock yields, costs of production and processing, and costs of fuel transportation.

As agricultural production activities, the model includes twelve major annual crops (corn, soybean, wheat, rice, barley, oats, sorghum, cassava, dry beans, cotton, peanut, and sugarbeet), four perennial crops (alfalfa, sugarcane, switchgrass, miscanthus), and beef-cattle production (in Brazil) under different pastures types and production systems. As the ethanol feedstocks, we consider sugarcane in Brazil and corn, crop residues (corn stover, wheat straw), switchgrass, and miscanthus in the US. The annual crops we include in the model cover more than $80 \%$ of the total cropland use in Brazil and in the US.

The land availability and crop yields are obtained from Agricultural Municipality Survey (IBGE, 2013) for Brazil, US and State Data Quick Stats 1.0. (USDA-NASS, 2011) for the US, and Argentina Department of Agriculture (MINIAGRI, 2011) for Argentina. Livestock yields in in each region of Brazil are derived from the beef-cattle data in AgraFNP (2008a) by calculating the heads of adult live animals per unit pasture area for each type of ranching system (i.e. extensive and semi-intensive) and activity (i.e. weaning, finishing, and complete cycle). The data on pasture lands in Brazil are obtained from the official reports by the Agricultural Census (IBGE, 2006). The production costs (all at regional level) are gathered from various sources including PECEGE (2008), AgraFNP (2008a, 2008b), CONAB (2011) EMBRAPA (2007a; 2007b), Barros et al. (2008), Chen et al. (2011), and Oreja (2005).

In the fuel sector, the model considers ethanol production costs, subsidies, co-product credits, costs of delivering feedstocks to refineries, marketing margins, and fuel taxes (which vary across states in Brazil). For gasoline, we assume a linear supply function in the US 
component $^{14}$ and a fixed price ${ }^{15}$ in the Brazil component. A linear VKT demand function is specified separately for each vehicle type (CV, FFV, and EDV) using a price elasticity, the base year price per VKT, and the total VKT in the base year. ${ }^{16}$ The ROW demand function for Brazilian ethanol is specified similarly. The base-year demand value is set as the difference between the total exports from Brazil minus the export to the US. The cost of ethanol transportation from Brazil to the ROW market is derived as the difference between the base-year ROW price and the average domestic price in Brazil. For ethanol exported to the US through the CBI countries, the transportation margin also includes the dehydration cost.

$\mathrm{CO}_{2}$ emissions are calculated for all livestock and crop activities and expressed in terms of the above-ground $\mathrm{CO}_{2}$ equivalent emissions $\left(\mathrm{CO}_{2} \mathrm{e}\right)$ associated with the carbon dioxide $\left(\mathrm{CO}_{2}\right)$, methane $\left(\mathrm{CH}_{4}\right)$, and nitrous oxide $\left(\mathrm{N}_{2} \mathrm{O}\right)$ emissions using their 100-year global warming potential factors. Due to the lack of detailed information on input uses with alternative tillage practices, we assume conventional tillage for all regions and crops produced in Brazil and Argentina. GHG emissions for crops include indirect emissions generated during the production of agricultural inputs (fertilizers etc.), and direct emissions from machinery uses and transportation. In the transportation component, as the emission factors we use the emissions per unit of fuel consumed without distinguishing vehicle type and fuel efficiency. Most of the emissions factors

\footnotetext{
${ }^{14}$ This assumption is based on Chen et al. (2014). Greene and Tishchishyna (2000) also suggest a linear gasoline supply function in the US. The assumption of linear supply and demand functions leads to a quadratic objective function which is computationally easier. However, if alternative forms are to be used (such as constant elasticity functions) the model can be modified in a straight forward manner (see footnote \#3 in Appendix). The resulting non-linear (and non-quadratic) programming problem can be solved without encountering significant computational difficulties.

15 The fixed price was $\mathrm{R} \$ 1.05$ per liter; this is approximately the refinery price before taxes, marketing margins of the blenders, and transportation costs from the refinery to the pump (ANP, 2013).

${ }^{16}$ For the US, the VKT by vehicle type and the fuel prices are obtained from the EIA (2010; 2008). The VKTs for Brazil are specified by vehicle type and by state. They are derived from the total consumption of gasoline (thus gasohol) and ethanol, the number of light duty vehicles registered, and kilometers per liter (kpl) for each vehicle type. We assume that the gasoline equivalent annual fuel consumption per vehicle is the same for all vehicle types. Since CVs consume gasohol only, the remaining gasohol is consumed by FFVs. EDVs consume only pure ethanol, therefore the remaining ethanol is consumed by FFVs. With this fuel allocation along with the kpl parameters by vehicle type, the total VKT and the price per VKT are calculated. The total consumption of fuels is obtained from EPE (2011), the number of vehicles is based on DENATRAN (2015), and kpl is based on several reports by INMETRO (2010).
} 
are generated by GREET $^{17}$ (Wang, 2007) while the rest are obtained from several sources

including Chen et al. (2011), Soares et al. (2009), Crago et al. (2010), Schmitt et al. (2011), CEFIC and ECTA (2011), and Cardoso (2012) ${ }^{18}$.

A complete description of the entire data set, the key supply and demand parameters, production costs and yields, and transportation costs between regions can be found in Nuñez et al. (2013) or can be available from the authors upon request.

\section{Results and Discussion}

The model is calibrated for the base-year conditions in Brazil and the US. When examining the impacts of alternative biofuel policies under future demand and supply scenarios, we first update the model parameters to reflect the projected domestic demand shifts (both domestic and global) and agricultural productivity improvements over the period 2007-2022. Updating those parameters is based on the historical trends in population growth and income growth (which together affect the food and transportation demands) and crop yield increases. For the scenario analysis, we first set our 'Reference Case' for 2022 assuming the followings: 1) the export demands for sugarcane ethanol are the US demand for undifferentiated advanced biofuels as stated in the RFS2 provisions ${ }^{19}$ and the projected imports from Brazil due to the mandates imposed by the European Union, Canada and China ${ }^{20}$; 2) the global sugar demand is the projected amount of sugar to be imported from Brazil (based on the historical trends); and 3) the sugarcane yield is the projected yield based on the average yield observed during 2007-2008 and the historical yield trend. In the alternative global market demand scenarios, we define 'strong'

\footnotetext{
${ }^{17}$ Greenhouse Gases, Regulated Emissions, and Energy Use in Transportation, Argonne National Laboratory.

18 The emission estimates used in the present analysis do not include emissions due to 'indirect land use changes' (ILUC). Quantifying ILUC is a difficult and highly controversial issue, and at present there is no consensus on the 'right' ILUC value associated each type of biofuel; therefore, we preferred not to include those effects. The endogenous model variables would not be affected if they were included, but the aggregate emissions (calculated expost) would be increased accordingly. Thus, the total emissions reported in the results section are lower bounds representing the emissions from fuel consumptions and emissions from direct land use changes.

${ }^{19}$ Namely, the total advanced biofuel mandate minus the sum of cellulosic biofuel and biodiesel targets, which is approximately 15 billion liters.

20 These are approximately 11 billion liters.
} 
and 'weak' market conditions as follows: 1) the strong global demand for ethanol is as in the Reference Case whereas the weak demand assumes that the RFS2 advanced biofuel mandate is eliminated and the ROW imports are at their 2007-2010 average levels; 2) the weak ROW sugar demand is the projected import from Brazil based on the 2007 import level whereas the strong sugar demand assumes a $44 \%$ increase with respect to the weak demand level (the latter is based on the observed increase in Brazil's export between 2007 and 2010). For the feedstock supply, we consider the Reference Case assumption as the 'high supply', while the 'low supply' condition assumes a 9\% yield reduction (reflecting the observed decline from 2007 to 2010). For each of these scenarios, we investigate the impacts of alternative blending rates varying between $15 \%$ and $30 \%$ and up to $100 \%$ reductions in the federal (CIDE) and state (ICMS) tax rates on domestic gasoline sales. We assume that all the other fuel taxes (PIS/PASEP and CONFIS) and the refinery gasoline control policy remain unchanged.

Some selected model results are reported in Table-1. The Reference Case is shown in the first column while the remaining columns, labeled by (a)-(j), display the percentage changes with respect to the Reference Case under the four alternative market scenarios described above. The results are presented in four blocks. Each block assumes a minimum or maximum ethanol blending rate (namely, $15 \%$ and 25\%) coupled with two extreme taxation alternatives, namely the base-year fuel tax rates, labeled as ' $\mathrm{F}-\mathrm{Tx}$ ' ${ }^{21}$, and complete elimination of the fuel taxes labeled as 'NoTx'. Below, we discuss the impacts of these alternatives on the fuel sector, land use, GHG emissions and social welfare.

\subsection{Effects on the Fuel Sector}

Several general deductions can be made based on the results displayed in Table-1. The first and most striking fact is the role of fuel taxes in the Brazil transportation fuels sector as a

\footnotetext{
${ }^{21}$ These are the federal gasoline (CIDE) and state (ICMS) tax rates. In the base year, the respective tax rates were $10 \%$ and $25 \%$ of the final price of gasoline before blending. All other taxes are kept at the base-year levels.
} 
whole, and in particular in the biofuel industry. The second column of each block (columns b, d, $\mathrm{g}$, and i) corresponds to the case where the fuel taxes are eliminated, which implies that Brazil applies the world price on gasoline sold in the domestic market. The results show that everything about the fuel markets would be affected dramatically by this single change. As expected, the total VKT (summed across all vehicle categories) increases (ranging between $4.6 \%$ and $4.9 \%$ relative to the Reference Case) as a result of the reduced gasohol consumer price (ranging between $32.4 \%$ and $36.8 \%$ ). The impacts of eliminating the fuel taxes on the sugarcane ethanol sector would be detrimental. The consumption of E100 by FFVs totally disappears, because FFV users switch to gasohol, and ethanol is produced only to meet the blending mandate rather than to substitute gasoline. Consequently, the total gasoline consumption goes up, as much as $87 \%$ to $104 \%$ depending on the availability of ethanol in the domestic market. This occurs because removing the taxes makes gasohol a more appealing fuel than pure ethanol, which leads to the substitution of ethanol with gasoline in the fuel mix. Therefore, the total consumption of ethanol goes down accordingly (between $65 \%$ and $79 \%$ ).

Unlike the tax instrument, the impacts of a reduced blending mandate on the transportation fuels sector and social welfare are not uniform; rather, they vary across the scenarios considered in Table-1. Nonetheless, some general conclusions can be made. Columns (a), (e), (f) and (j) report the results obtained with a $15 \%$ blending mandate where the fuel taxes are maintained at the Reference Case levels. Therefore, the results in these columns leave out the role of fuel taxes and provide a meaningful evaluation of the impact of blending mandate alone. It is clear from these results that the impact of a reduced mandate rate on the total VKT demand would be insignificant (varying between $-0.7 \%$ and $-0.1 \%$ ). However, the composition and prices of transportation fuels would be impacted considerably. A reduced blending rate makes gasohol more expensive since it contains a more expensive fuel (gasoline) in a larger proportion. This 
encourages FFVs to switch from gasohol to pure ethanol, thus substituting the gasoline in the gasohol mix consumed by this car category with pure ethanol. While E100 consumption by FFVs goes up, between $20 \%$ and $37 \%$, the consumption of gasoline goes down by about $20 \%$ in three out of the four cases, namely columns (a), (f), and (j). An unintuitive result reported in Table-1 is the impact of reducing the blending rate on Brazil's ethanol exports. When the blending rate is reduced, one expects an increase in the ethanol exports because less ethanol will be needed in the gasohol mix consumed in the domestic market, thus releasing some ethanol for exports. While this is true for the ethanol used as a complementary fuel by conventional cars, a reduced blending rate changes the fuel choice for FFVs that switch from gasohol to E100. The increase in E100 demand as a substitute to gasohol is far more than the reduction in the demand for ethanol as a complementary fuel. In the aggregate, the total demand for ethanol in the domestic market goes up substantially. This interesting result is due to the large share of FFVs in the light-duty vehicle fleet ${ }^{22}$, a unique feature of the Brazil transportation sector, which makes the fuel policy analysis complex and justifies the use of the model we developed here.

The results presented in Table-1 correspond only to the combinations of the extreme changes in the fuel tax and ethanol blending rates considered in the analysis. The entire spectrum of the model results for VKT under all combinations of the blending rate and fuel tax rate reduction (ranging from $15 \%$ to $30 \%$ and up to $100 \%$, respectively) is illustrated in Figure 5. Similarly, Figure 6 displays the effects on ethanol price. Each sheet in the figures corresponds to one of the four market conditions (namely a strong/weak market demand for ethanol and sugar coupled with high/low feedstock supply). The directions of changes are as outlined above except that changes in the sectoral performance indicators, environmental impacts, and welfare measures occur gradually as the two policy instruments are varied systematically. Figure 5 shows

\footnotetext{
${ }^{22}$ The share of FFVs in the Brazil light-duty vehicle fleet is projected to increase to $85 \%$ by 2022 . We assumed this share in the model simulations.
} 
that the total VKT in Brazil goes down under all four scenarios when either the blending rate is reduced or the fuel tax is increased. Although the average VKT reduction may seem insignificant, it is equivalent to nearly two days of no driving by all light-duty vehicles in Brazil. The gasoline consumption by FFVs shifts upward when the amount of sugarcane converted to ethanol is reduced due to a yield decline. It also rises when the fuel tax rate is reduced. The price of ethanol declines as the tax rate is reduced up to $50 \%$, but after that level it increases again because of the higher demand for gasohol which also intensifies the demand for anhydrous ethanol (see Figure 6).

\subsection{Effects on Sugarcane Production}

Responding to strong sugar and ethanol demands in the global markets, farmers would alter their crop pattern in favor of sugarcane. In contrast, substantial acreage reductions would occur when the world demands for sugarcane products are weak. These facts are apparent in Table-1 when columns (f) and (g) (weak demands and high supply) are compared against columns (a) and (b) (strong demands and high supply). The simulation results show that the land allocated to sugarcane can go down to as much as $50 \%$ of the base-year land allocation when the global demand for sugarcane products is weak. Similar conclusions can be made under the low feedstock supply conditions by comparing columns (c), (d), and (e) against columns (h), (i), and (j). Besides these expected results, Table-1 also shows that the land allocated to sugarcane is highly sensitive to fuel policies, in particular to fuel taxes. For instance, even under the strong global market conditions, the sugarcane acreage shrinks by more than $20 \%$ with respect to the Reference Case level when the fuel tax is eliminated (column (d)). An acreage reduction under high sugarcane yield and strong global demands for ethanol and sugar may seem surprising. This is explained by the reduced demand for ethanol in the domestic market. As discussed earlier, elimination of the fuel taxes makes gasohol a more appealing fuel and encourages FFVs to 
switch from E100 to gasohol. This, in turn, reduces the domestic demand for ethanol, therefore the demand for sugarcane feedstock. The reductions in columns (c), (d), and (e) are mainly due to the low sugarcane yield assumption, which reduces the attractiveness of sugarcane vis-à-vis the other major field crops. This is pronounced more when the fuel tax is reduced, as shown in column (d). The drastic acreage reductions in columns (f) and (g) (even when the yield is set at the historical average level) are due to the low global demand for sugarcane products and low blending rate in the domestic market, both of which reduce the demand for sugarcane. This effect is pronounced further when the tax rate on fuels is eliminated (column (h)), which is again an expected result. An unintuitive result that needs to be explained is the slight increase in sugarcane acreage when the ethanol blending rate is reduced while all else is the same as in the Reference Case (see column (e)). As discussed earlier, reducing the blending rate reduces the demand for ethanol as a complementary fuel, but at the same time it increases the demand for E100 by FFVs switching from gasohol to pure ethanol. The net effect is an increase in the demand for ethanol; therefore, the land allocated to sugarcane expands.

\subsection{Environmental Effects}

It might be expected that mandating a smaller blending rate would increase the total GHG emissions (in $\mathrm{CO}_{2}$ e terms) from transportation fuels consumed in Brazil since this would increase the amount of gasoline (a dirtier fuel) in the fuel consumption by conventional vehicles. However, a reduced blending rate simultaneously affects the possibility of switching from gasohol to E100 by FFVs. Thus, the net effect would be ambiguous. The simulation results displayed in columns (c) and (e) and columns (h) and (j) of Table-1 show that the effect of a lower blending rate (a more gasoline-intensive fuel mix) on GHG emissions is dominated by the emission reduction effect of increased ethanol consumption by FFVs. The net change in GHG emission is moderate in the case of strong global market conditions for ethanol and sugar (where 
the net emission reduction goes up to $2.5 \%$, see column (e)), but it is significant when the global markets are weak (see columns (h) and (j), where the net emission reduction goes up from $0.8 \%$ to $5.2 \%)$.

On the other hand, a fuel tax rate reduction always increases the GHG emissions. This is because of the strong effect of fuel taxes on fuel consumption and particularly on fuel choice. Tax rate reductions beyond a certain level make gasohol a more appealing fuel for consumers. When the fuel taxes are totally eliminated, the domestic GHG emissions from transportation fuels goes up, ranging between $17 \%$ and $22 \%$ with respect to the Reference Case level under different scenarios, as indicated in Table-1 by columns (b), (d), (g) and (i). A comparison of columns (a) and (b) demonstrates that all else being the same eliminating the fuel taxes alone increases the GHG emissions as much as $22 \%$ (from $4.3 \%$ reduction in column (a) to $22.5 \%$ more emissions in column (b), both with respect to the Reference Case emissions level). Similar findings are reported in columns (c) and (d), columns (f) and (g), and columns (h) and (i), which show that eliminating the fuel taxes has a negative environmental impact regardless of the global market demands for sugarcane products and sugarcane supply conditions. The strong global demand for sugarcane products exacerbates the situation further. In this case, a larger portion of the sugarcane production is crushed for sugar and the amount of ethanol available in the domestic market is reduced. This raises the price of ethanol in the domestic market to a level that makes E100 a more expensive and less appealing fuel relative to gasohol. Consequently, FFVs switch from E100 to gasohol and the GHG emission increases. This fact is displayed clearly in Figure 7 and Table- 1 by the columns that differ only in terms of the global demands for sugarcane products. For instance, a comparison of columns (a) and (f) shows that under a stronger world demand for sugar and ethanol (column (a)), the GHG emission is $4.3 \%$ lower than the Reference Case level. Under the weak global market conditions, the emission level would be 
6.1\% lower. Similar findings are observed when columns (b), (c), (d) and (e) are compared against columns (g), (h), (i) and (j), where the GHG emissions are higher than the Reference Case level in some of these scenarios. The differences are more pronounced under the strong global markets for sugarcane products.

The phenomenon described above has occurred recently in Brazil. The strong global sugar and ethanol markets and poor sugarcane yields reduced the supply and increased the price of ethanol in the domestic market during 2007-2011. This is characterized to some extent by the second block of results in Table-1 (columns (c) through (e)). Responding to this, the government reduced the blending rate from 25\% to 20\% between October 2011 and May 2013.

Simultaneously, to protect the fuel consumers and control potential inflationary effects of higher fuel prices, the federal fuel tax rates were also reduced significantly (in June 2012 all federal charges were reduced to zero). Referring to Figure 7, these conditions must have led to a roughly $15 \%$ increase in the GHG emissions from transportation fuels consumed in Brazil. If the blending rate and fuel tax rates were maintained at their base levels, this would reduce the VKT (by $0.3 \%$ ) and increase GHG emissions insignificantly (by $0.4 \%$ ) with respect to the Reference Case. Note, however, that this would be at the expense of social welfare loss $(0.2 \%$, see column (c) in Table-1). The policy change was an immediate response to a crisis and there may be good reasons that justify the change in the short term. Our analysis implies that a low fuel tax policy has damaging impacts on the global environment. Recently, the global sugar and ethanol markets have become weaker. The first is due to an oversupply of sugar in the world, while the latter is due to a weaker US demand for ethanol as a result of the adjustment in the RFS mandates (particularly due to the reduction in the advanced biofuel mandate requiring less sugarcane ethanol to be imported from Brazil). Simultaneously, the sugarcane yield (supply) has gone up (even above the historical average). This increased the ethanol supply in the Brazil domestic 
market and reduced the price. The global market conditions and sugarcane supply assumed in columns (f) and (g) of Table-1 characterize this situation. Our results suggest that under such conditions, mandating a low blending ratio (such as 15\%) would shrink the sugarcane area substantially (33\%) relative to the Reference Case. The results also show that a low fuel tax rate would be quite harmful to the global environment because of the increased GHG emissions. Eliminating the fuel taxes altogether would be extremely discouraging for the sugarcane and ethanol industries, which would cut back their production and consumption of ethanol since FFVs would switch to gasohol. This would be damaging for the global environment by increasing the GHG emissions from transportation fuels (by about $22 \%$, as presented in column (g)). Under such circumstances, a low blending rate and high fuel taxes would be beneficial for both the global environment and the Brazil sugarcane/ethanol industry. This would promote the sugarcane production and consumption of ethanol by FFVs as a substitute to gasohol. It should be noted, however, that this policy has unfavorable consequences for consumers due to higher prices they pay for transportation fuels.

\subsection{Welfare Effects}

The two fuel policy instruments considered here have important welfare distribution effects. As discussed earlier, fuel consumers would be significantly worse off when the ethanol blending rate is reduced while the ethanol sector benefits from it. This is evident in Table-1 when column (a) is compared with the Reference Case. Lowering the blending rate alone (while keeping all else - in particular the fuel taxes - the same) reduces the domestic social surplus ${ }^{23}$ (by $0.6 \%$ ) despite the significant surplus gains accruing to ethanol producers (15\%). This is mainly because of the increased gasohol prices consumers have to pay ( $7.9 \%$ higher). While the magnitude of gains and losses may vary substantially when the underlying demand and supply

\footnotetext{
${ }^{23}$ Social surplus (or welfare) is defined here as the sum of consumers' and producers' surpluses and government revenue.
} 
conditions in sugarcane and ethanol markets are altered, the directions of changes remain the same. For example, a comparison of columns (h) and (j) (that assume weak global demands for ethanol and sugar, and poor sugarcane productivity) shows that when the blending rate is reduced from $25 \%$ to $15 \%$ (all else being the same), the social surplus loss increases while the surplus of ethanol producers goes up relative to the Reference Case.

A lower fuel tax rate helps consumers greatly under all of the demand and supply scenarios considered here while producers suffer welfare losses from it. This justifies the tax reduction implemented by the government together with the blending mandate reduction in response to the ethanol supply shortages and high ethanol prices observed in Brazil during 20102011. During that period, global markets for sugarcane products were strong and the sugarcane yields were low. Figure 8 displays the entire spectrum of welfare implications of alternative fuel tax rate and blending rate combinations on ethanol producers' economic surplus. As depicted in the figure, a lower blending mandate along with a high tax reduction worsens producers' surplus gradually, but the changes are relatively insignificant compared to the gains resulting from an increase in the fuel taxes. Columns (a) and (b) in Table-1 also indicate this point. Elimination of the fuel taxes (column (b)) offsets the consumers' surplus loss resulting from a lower blending rate (consumption of a more gasoline-intensive fuel mix), and even provides a significant positive social welfare gain $(\sim 1 \%)$. However, this results in a dramatic economic surplus loss ( $78 \%)$ for ethanol producers. A similar effect is observed under the low feedstock supply conditions and high blending rates. Comparing column (c) against column (d), which differ only in terms of the fuel tax rates, we see that the producers' surplus loss relative to the Reference Case goes up from $4.6 \%$ to $68.8 \%$ while the aggregate social surplus moves from a net loss of $0.2 \%$ to a net gain of $1.3 \%$. This occurs because of the substantially reduced amount of ethanol sold in the domestic market as a result of FFVs switching from E100 to gasohol. 
Columns (f) and (g) demonstrate that when the foreign markets for sugarcane products are not as strong while the feedstock productivity is high, implementing a low blending rate would not be a good policy. This would raise the price of fuels (particularly gasohol) and shrink the ethanol industry and sugarcane production (the latter declines by $10 \%$ relative to the Reference Case). The largest social economic surplus loss (2.2\%) occurs in this case (see column (f)). Reducing the fuel taxes together with the blending rate would be disastrous for the ethanol industry, in which case ethanol would be produced only as a complementary fuel to meet the blending mandate. The sugarcane production would shrink further (to 33\% of the Reference Case level), and the ethanol producers' surplus would be substantially lower (as much as 78\%) relative to the Reference Case.

Finally, reducing the fuel taxes not only affects the economic surplus of ethanol producers and fuel consumers, but it also affects the government's tax revenues considerably (see Figure 9). Elimination of the fuel taxes would reduce the government revenues from transportation fuel sales by about $70 \%$ relative to the Reference Case under all scenarios considered here. This is also shown in Table-1, columns (b), (d), (g), and (i). Thus, a low profile biofuel policy (low taxes and low blending rates) would damage the ethanol sector, the environment, government revenues, and society as a whole.

In view of the above results, our analysis shows that staying on course and pursuing the goals of the renewable fuel program in Brazil is a good policy regardless of the world market conditions for sugarcane products. This is especially the case when the global markets are weak and sugarcane productivity is high. ${ }^{24}$ Responding to the relatively high sugarcane production and unfavorable conditions in the world sugar markets and ethanol markets, the Brazilian government increased the blending mandate rate back to 25\% in May 2013. Simultaneously, the

\footnotetext{
${ }^{24}$ This was the situation in 2013 and 2014, but the supply is expected to be weak again in 2015 due to the recent drought that affected the crop yields including sugarcane.
} 
refinery price of gasoline was increased. Together, these two policy instruments encouraged the consumption of ethanol in the domestic market. Although the conventional vehicle users were harmed by these changes, if our model results are truly representative the impacts on ethanol producers, FFV users, and society as a whole must have been positive. The environmental benefit (i.e. GHG emission reduction, which is not measured) must also be substantial.

\section{Concluding Remarks and Policy Implications}

This paper highlights how the biofuel economy and environment can be sensitive to the fuel policy instruments implemented in Brazil. Our empirical results show that under a lower blending rate conventional light-duty vehicles would be driven significantly less due to high fuel prices, while the use of flex-fuel and ethanol-dedicated vehicles would be affected at an insignificant rate. However, when the reduced supply of sugarcane crushed for ethanol and reduced ethanol blending mandates are incorporated together, the distance driven by both vehicle categories would be reduced considerably. On the other hand, fuel tax appears to be a very strong and effective policy instrument. Our simulation results demonstrate that lowering the fuel tax rates adversely affects the competitiveness of sugarcane ethanol against gasoline blends, and beyond a certain level it completely eliminates the possibility of substituting gasoline with ethanol because lower tax rates encourage flex-fuel car users to switch from pure ethanol to gasohol. The two policy instruments have important economic impacts on producers' and consumers' welfare also. Specifically, i) reducing the blending rate alone always reduces the consumers' economic surplus while increasing the producers' surplus, ii) a reduction in fuel taxes is always beneficial for consumers, but it has an opposite effect on ethanol producers. The net effect of a combined policy (lower taxes and lower blending rates) depends on the individual effects of each policy. Our model results provide estimates of those effects for a full spectrum of changes in these two policy instruments (Figures 5-9). While being advantageous in terms of 
social welfare, a reduced fuel tax policy has serious environmental impacts and increases the GHG emissions from transportation fuels consumed in Brazil. Our empirical results show that the increase in the total GHG emissions may be as much as $22 \%$.

Based on the model results, we conclude that the reduction in the ethanol blending rate during 2010-2012 harmed the conventional light-duty vehicle users who were forced to consume a more gasoline-intensive and more expensive fuel (because of the higher tax on gasoline relative to ethanol). Some of that effect may have been compensated by the tax rate reduction; however, if our model results are representative, this latter policy may have caused a serious environmental damage because of the increased GHG emissions from fuel consumption. The model results also suggest that significant economic surplus losses occur under a negative ethanol supply shock (low feedstock yields, as observed during 2010-2012). Although the distribution of welfare losses between consumers and producers would vary depending on the tax rate and blend rate adjustments, as a whole society would incur a considerable loss, which may be as much as $2.2 \%$. Lowering the fuel taxes can improve the aggregate social welfare (measured as the sum of producers' and consumers' economic surplus) because of the positive impact on fuel consumers, which may outweigh the losses accruing to agricultural producers and the ethanol industry. The downside of lower fuel tax rates is the potential increase in GHG emissions from transportation fuels making a costly trade-off for society.

These results clearly demonstrate (and quantify) how important fuel taxes are in terms of the adoption of renewable fuels even in a country like Brazil endowed with vast amount of natural resources (land in particular) and a relatively mature biofuel industry. While adjustments in the fuel tax rates and ethanol blending rate can be useful policy instruments to deal with serious ethanol supply shortages in the short term, introducing policy measures to improve agricultural productivity (e.g., optimum sugarcane replanting cycle, adoption of high-yield 
sugarcane varieties, livestock intensification, etc.), and resource allocation schemes that are consistent with renewable fuel policy objectives can be more desirable in the long term. Another policy option might be expanding the storage capacity of both sugar and ethanol to deal with short-run supply volatilities. The perennial nature of sugarcane does not allow producers to respond rapidly to short-term fluctuations in the global sugar and ethanol markets, but reasonably large buffer stocks would be effective means to meet the global demands with little disturbance in the domestic markets. This would be beneficial for both domestic producers and consumers; it would also be beneficial for the global environment.

An important topic that is left out in the present analysis is the possibility of producing biofuel from bagasse (cellulosic biomass produced as a by-product of sugarcane processing). In the current model we assume that bagasse is used only for power generation (consumed on site or sold to the grid, both valued at an exogenous electricity price). The additional pathway of processing bagasse to second generation biofuel can be simulated by allowing its use for both biofuel and power generation; the model would choose the pathway that is more advantageous. This would require some critical data, in particular the costs and yields of producing biofuel from bagasse, which are still subject to high uncertainty. If technological difficulties are overcome, sugarcane bagasse can be the most promising biofuel feedstock because of its low cost and availability in large amounts at existing facilities without encountering significant storage, logistics and transportation difficulties. Recent developments in the industry (e.g. the commercial facility that is just made operational by Raizen and Iogen partnership) may shed some light on this issue. An added comparative advantage of cellulosic biofuel from bagasse is its substantially lower GHG emission factor. This makes it an advanced biofuel and presents great export potential to the US since second generation (cellulosic) biofuels constitute an important component of the RFS mandates. 
The purpose of this study is not to prescribe a single best choice for the policy instruments considered here. Rather, our analysis aims to indicate and quantify the implications of alternative choices under different market conditions and the socioeconomic objective(s) of the public policy makers. The empirical results presented here can provide useful guidance if the conditions in the sugarcane and end-product markets can be predicted with reasonable certainty. 


\section{References}

AgraFNP, 2008a. ANUALPEC, Anuario da Pecuária Brasileira. São Paulo: Agra FNP Pesquisas

AgraFNP, 2008b. AGRIANUAL, Anuario da agricultura Brasileira. São Paulo: Agra FNP Pesquisas

ANP, 2011. Estruturas de formação dos preços [WWW Document]. Agência Nac. do Petróleo, Gás Nat. e Biocombustíveis. URL http://www.anp.gov.br (accessed 5.18.14).

ANP, 2013. Anuário Estatístico Brasileiro do Petróleo, Gás Natural e Biocombustíveis [WWW Document]. Agência Nacional do Petróleo, Gás Natural e Biocombustíveis. URL http://www.anp.gov.br (accessed 2.20.14).

Araujo, R.R. De, Lu, K., 2010. The Ethanol Trade Development Between China and Brazil. J. Cambridge Stud. 5, 104-113.

Babcock, B., Moreira, M., Peng, Y., 2013. Biofuel taxes, subsidies, and mandates: Impacts on US and Brazilian markets. CARD - Cent. Agric. Rural Dev. 13-SR 108.

Barros, G. S. C., Alves, 1. R. A., Ballaminut, C. E. C., Felipe, F. I. , Ribeiro, R.G., Beduschi, G., Osaki, M. , Ribeiro, G.G, 2008. Custo de produção na safra 2007/08 e Perspectivas para 2008/09, região de cândido Mota (SP): Mandioca, cana-de-açúcar, milho, trigo, soja, Café, pecuária de corte e pecuária de leite. CEPEA/ESALQ/USP

Cardoso, A. da S., 2012. Avaliação das emissões de gases de efeito estufa em diferentes cenários de intensificação de uso das pastagens no Brasil Central. Universidade Federal Rural Do Rio De Janeiro.

CEFIC and ECTA, 2011. Guidelines for Measuring and Managing CO 2 Emission from Freight Transport Operations, Transport.

Chen, X., Huang, H., Khanna, M., and Önal, H. 2014. Alternative Transportation Fuel Standards: Welfare Effects and Climate Benefits. Journal of Environmental Economics and Management, 67: 241-257.

Chen, X., Huang, H., Khanna, M., Önal, H., 2011. Meeting the Mandate for Biofuels: Implications for Land Use, Food and Fuel Prices. In The Intended and Unintended Effects of U.S. Agricultural and Biotechnology Policies, eds. J. G. Zivin and J. Perloff, University of Chicago Press.

CONAB, 2011. Custos de Produção [WWW Document]. Indicadores da Agropecuária. Cia. Nac. Abast. URL http://www.conab.gov.br/conteudos.php?a=1546\&t=2 (accessed 12.01.13).

Crago, C.L., Khanna, M., Barton, J., Giuliani, E., Amaral, W., 2010. Competitiveness of Brazilian sugarcane ethanol compared to US corn ethanol. Energy Policy 38, 7404-7415. 
de Freitas, L.C., Kaneko, S., 2011a. Ethanol demand in Brazil: Regional approach. Energy Policy 39, 2289-2298.

de Freitas, L.C., Kaneko, S., 2011b. Ethanol demand under the flex-fuel technology regime in Brazil. Energy Econ. 33, 1146-1154.

de Gorter, H., Drabik, D., Kliauga, E., Timilsina, G.R., 2013. An Economic Model of Brazil's Ethanol-Sugar Markets and Impacts of Fuel Policies. World Bank Policy Res. Work. Pap. 6524.

DENATRAN, 2015. Anuario Denatran [WWW Document]. Dep. Nac. Transito. URL http://www.denatran.gov.br/frota.htm (accessed 6.30.15).

EIA, 2008. Motor Gasoline and Diesel Retail Prices, U.S. City Average, Annual 1949-Current [WWW Document]. US Department of Energy. URL http://www.eia.gov/petroleum/ (accessed 2.09.12).

EIA, 2010. Annual Energy Outlook 2010. [WWW Document]. US Department of Energy. URL http://www.eia.gov/forecasts/aeo/ (accessed 2.20.12).

EMBRAPA, 2007a. Estimativa do Custo de Produção de Arroz Irrigado e de Terras Altas, Safra 2007/08, para Mato Grosso do Sul e Mato Grosso. Comun. Técnicos 137.

EMBRAPA, 2007b. Estimativa do Custo de Produção de Mandioca Industrial, Safra 2007. Comun. Técnicos 133.

Empresa de Pesquisa Energetica, 2013. Balanço Energético Nacional [WWW Document]. URL https://ben.epe.gov.br/ (accessed 4.13.13).

EPE, 2011. Balanço Energético Nacional. Empresa de Pesquisa Energetica. Rio de Janeiro. Brasil.

Fecombustíveis, 2011. Gasolina. De volta ao topo, in: Lubrificantes, F.N. do C. de C. e de (Ed.), Relatório Anual Da Revenda de Combustíveis. pp. 19-29.

Greene, D.L. and Ahmad, S., 2005. Costs of Oil Dependence: A 2005 Update. No. ORNL/TM2005/45, Oak Ridge National Laboratory, Oak Ridge, Tennessee.

Greene, D.L. and Tishchishyna, N.L., 2000. Costs of Oil Dependence: A 2000 Update. No. ORNL/TM-2000/152, Oak Ridge National Laboratory, Oak Ridge, Tennessee.

IBGE, 2006. Agricultural Census. [WWW Document]. Instituto Brasileiro de Geografia e Estatística URL

http://www.ibge.gov.br/home/estatistica/economia/agropecuaria/censoagro/default.shtm (accessed 8.01.12). 
IBGE, 2013. Produção Agrícola Municipal [WWW Document]. Instituto Brasileiro de Geografia e Estatística URL http://www.sidra.ibge.gov.br/bda/agric/default.asp?z=t\&o=11\&i=P (accessed 3.3.12).

INMETRO, 2010. Tavela PBE Veicular. Instituto Nacional de Metrologia, Qualidade e Tecnologia [WWW Document]. URL http://www.inmetro.gov.br/consumidor/tabelas_pbe_veicular.asp (accessed 2.27.13).

MAPA, 2010. Anuário Estatístico da Agroenergia. Brasilia, Distrito Federal - Brasil.

MAPA, 2012. Orientações Técnicas [WWW Document]. Coord. Agroenergia (CGAE). Secr. Produção e Agroenergia (SPAE). Ministério da Agric. Pecuária e Abast. URL http://www.agricultura.gov.br/desenvolvimento-sustentavel/agroenergia/orientacoes-tecnicas (accessed 10.12.13).

McCarl, B.A., Spreen, T.H., 1980. Price Endogenous Mathematical Programming as a Tool for Sector Analysis. Am. J. Agric. Econ. 62, 87-102.

MINIAGRI, 2011. Estimaciones Agricolas [WWW Document]. Ministerio de Agricultura, Ganadería y Pesca. URL http://www.siia.gov.ar/sst_pcias/estima/estima.php (accessed 9.25.13).

Nuñez, H.M., Önal, H., Khanna, M., 2013. Land use and economic effects of alternative biofuel policies in Brazil and the United States. Agric. Econ. 44, 487-499.

OECD-FAO, 2011. OECD-FAO Agricultural Outlook 2011-2020. [WWW Document]. Organisation for Economic Co-operation and Development (OECD) and the Food and Agriculture Organization (FAO) of the United Nation. URL http://www.agri-outlook.org/ (accessed 5.05.12).

Onal, H., McCarl, B.A., 1991. Exact Aggregation in Mathematical Programming Sector Models. Canadian Journal of Agricultural Economics/Revue canadienne d'agroeconomie 39, 319-334.

Oreja, S., 2005. Cálculo de margen bruto, costos operativos, márgenes agrícolas [WWW Document]. URL http://www.buscagro.com/biblioteca/SergioCarlosOreja/Introduccion.htm (accessed 6.30.13).

Pacini, H., Silveira, S., 2011. Consumer choice between ethanol and gasoline: Lessons from Brazil and Sweden. Energy Policy 39, 6936-6942.

PECEGE, 2008. Custos de Produção de Cana-De-Açúcar, Açúcar e Etanol no Brasil: Safra 2008/2009. [WWW Document]. Universidade de São Paulo - USP Escola Superior de Agricultura "Luiz de Queiroz" - ESALQ Departamento de Economia, Administração e Sociologia Programa de Educação Continuada em Economia e Gestão de Empresas - PECEGE. URL http://pecege.dyndns.org/ (accessed 5.05.12). 
PETROBRAS, 2011. Aumento nos postos reflete o preço do etanol adicionado à gasolina [WWW Document]. Fados e Dados. URL http://fatosedados.blogspetrobras.com.br/informacoesmercado-gasolina-etanol/ (accessed 4.30.12).

Portal Brasil, 2011a. Governo reduz percentual de etanol que é misturado à gasolina [WWW Document]. URL http://www.brasil.gov.br/noticias/arquivos/2011/08/30/governo-reduzpercentual-de-etanol-que-e-misturado-a-gasolina (accessed 4.30.12).

Portal Brasil, 2011b. Redução da quantidade de etanol na gasolina já está valendo [WWW Document]. URL http://www.brasil.gov.br/noticias/arquivos/2011/10/03/reducao-da-quantidadede-etanol-na-gasolina-ja-esta-valendo (accessed 12.12.13).

Salvo, A, and C Huse. 2013. "Build It, but Will They Come? Evidence from Consumer Choice between Gasoline and Sugarcane Ethanol.” Journal of Environmental Economics and Management 66: 251-279.

Schmitt, W.F., Szklo, A., Schaeffer, R., 2011. Policies for improving the efficiency of the Brazilian light-duty vehicle fleet and their implications for fuel use, greenhouse gas emissions and land use. Energy Policy 39, 3163-3176.

Serra, T., Zilberman, D., Gil, J., 2011. Price volatility in ethanol markets. Eur. Rev. Agric. Econ. 38, 259-280.

Soares, L., Alves, B., Urquiaga, S., Boddey, R., 2009. Mitigação das emissões de gases efeito estufa pelo uso de etanol da cana-de-açúcar produzido no Brasil. EMBRAPA.

Takayama, T., Judge, G.G., 1971. Spatial and temporal price and allocation models. NorthHolland Pub. Co.

UNICA, 2013. Dados e Cotações - Estatísticas [WWW Document]. Uniao da Ind. Cana Acucar. URL http://www.unica.com.br/dadosCotacao/estatistica/ (accessed 5.19.14).

USDA-NASS, 2011. U.S. and State Data Quick Stats 2.0. [WWW Document]. Data Stat. URL http://www.nass.usda.gov/Data_and_Statistics/Quick_Stats_1.0/index.asp (accessed 2.19.13).

Wang, M. 2007. The Greenhouse Gases, Regulated Emissions, and Energy Use in Transportation (GREET) Model, Version 1.7. Argonne National Laboratory. 
Table 1 Simulated economic, land use and environmental impacts of Brazil fuel policies under alternative demand and supply conditions for the sugarcane industry, $2022^{\mathrm{a}}$

\begin{tabular}{|c|c|c|c|c|c|c|c|c|c|c|c|}
\hline \multirow{3}{*}{$\begin{array}{l}\text { Sugarcane Yield } \rightarrow \\
\text { Blending Rate } \rightarrow \\
\text { Tax Rate } \rightarrow\end{array}$} & & \multicolumn{5}{|c|}{$\begin{array}{l}\text { Strong Ethanol Demand } \\
\text { Strong World Sugar Demand }^{\mathrm{d}}\end{array}$} & \multicolumn{5}{|c|}{$\begin{array}{c}\text { Weak Ethanol Demand }{ }^{\mathrm{c}} \\
\text { Weak World Sugar Demand }^{\mathrm{d}}\end{array}$} \\
\hline & & $15 \%$ & $15 \%$ & $25 \%$ & $25 \%$ & $15 \%$ & $15 \%$ & $15 \%$ & $25 \%$ & $25 \%$ & $15 \%$ \\
\hline & Ref. Case ${ }^{\text {b }}$ & (a) & (b) & (c) & (d) & (e) & (f) & $(\mathrm{g})$ & (h) & (i) & (j) \\
\hline Vehicle Km Traveled (Bil) & 730.7 & -0.3 & 4.6 & -0.3 & 4.7 & -0.7 & -0.1 & 4.7 & -0.2 & 4.9 & -0.6 \\
\hline Eth Demand Total (Bil lt) & 39.9 & 16.7 & -79.0 & -4.2 & -64.9 & 7.1 & 19.4 & -79.0 & -2.2 & -64.8 & 15.2 \\
\hline Gas Demand by FFV (Bil lt) & 13.2 & -37.8 & 161.2 & 6.9 & 138.9 & -20.7 & -42.3 & 161.2 & 3.4 & 139.5 & -35.7 \\
\hline E100 Price $(\$ / 1 t)$ & 0.73 & 5.5 & 0.6 & 2.6 & 7.7 & 7.6 & 4.4 & -1.1 & 1.7 & 0.0 & 8.0 \\
\hline Gasohol Consumer Price (\$/lt) & 1.16 & 7.9 & -32.4 & 0.8 & -35.6 & 8.6 & 7.6 & -32.5 & 0.5 & -36.8 & 8.2 \\
\hline Ethanol Exports (Bil lt) & 14.6 & -0.7 & 43.1 & -61.8 & -3.1 & -66.3 & -85.8 & 36.3 & -100.0 & -79.0 & -100.0 \\
\hline Sugarcane Area (Mil Ha) & 10.6 & 7.0 & -26.3 & -3.7 & -21.2 & 0.9 & -10.6 & -33.0 & -15.0 & -40.7 & -7.2 \\
\hline
\end{tabular}

Notes: ${ }^{\text {a }}$ The units of figures in the 'Reference Case' column are given in parentheses in the row descriptions. The figures reported in columns (a)-(j) are percentage changes with respect to the Reference Case. ${ }^{\mathrm{b}}$ The Reference Case assumes strong ethanol demand and weak sugar demand in the world markets, projected sugarcane yield in 2022, 25\% blending rate, and the base-year fuel tax rates in Brazil. ' 'Strong Ethanol Demand' means that the world mandates are in place, while 'Weak Ethanol Demand' means that the mandates are removed. 'Weak Sugar Demand' represents the average global demand from Brazil observed in 2007-2008. 'Strong Sugar Demand' means a 44\% increase in the world sugar demand with respect to the Reference Case level. 'High Sugarcane Yield' represents the projected yield based on the observed average yield during 2007-2008. 'Low Sugarcane Yield' represents a 9\% reduction with respect to the high yield. ' 'F-Tx' means full tax (base year value). ' $N o T x$ ' means fuel tax is eliminated. 
Figure 1. World sugar market trends, 1984-2014

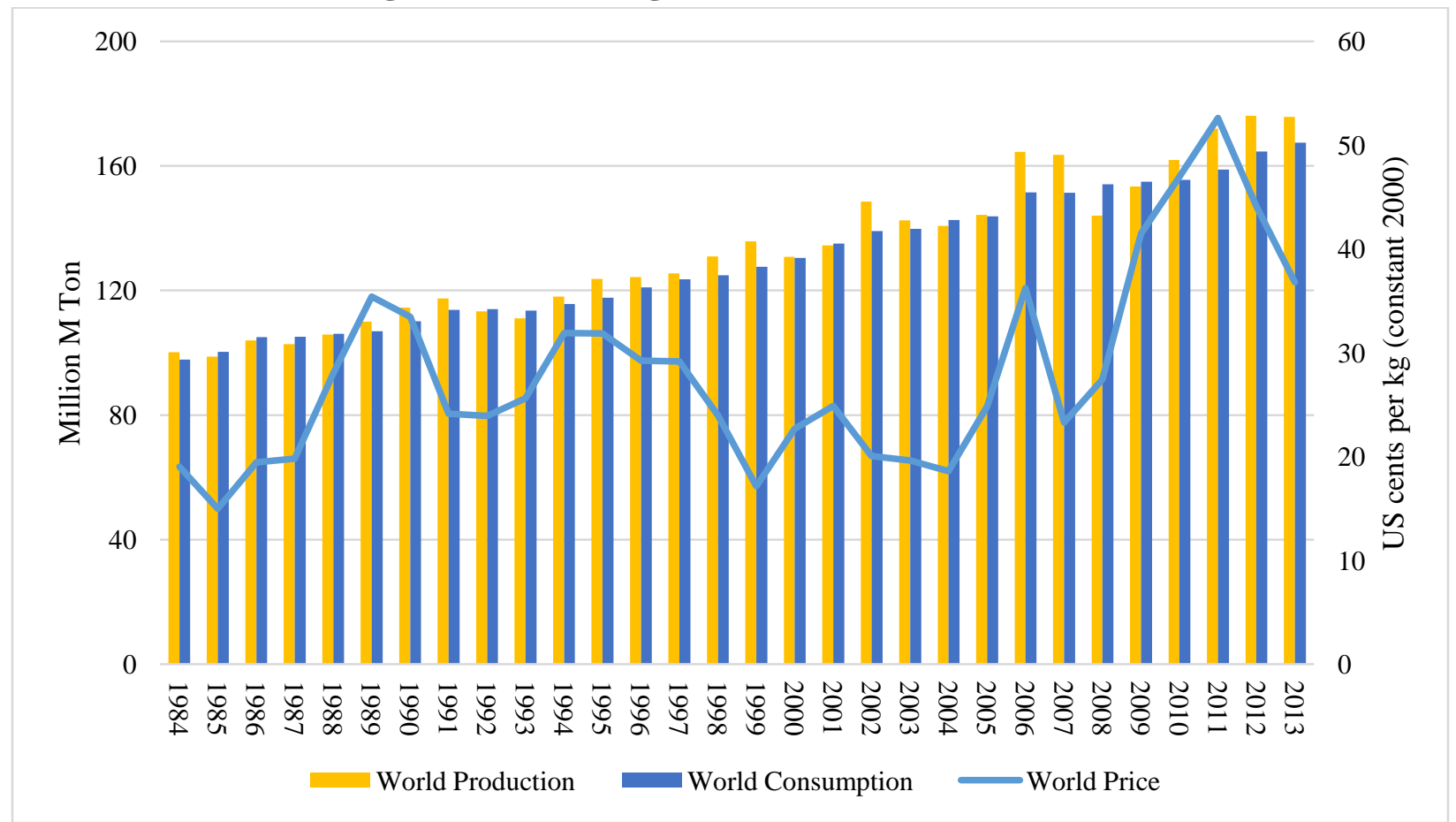

Source: USDA-FAS (2014) and World-Bank (2014)

USDA-FAS. (2014). Production, Supply and Distribution online. PSD [WWW Document]. URL http://www.fas.usda.gov/psdonline/psdQuery.aspx (accessed 9.21.14)

World-Bank (2014). World DataBank. Global Economic Monitor (GEM) Commodities PSD [WWW Document]. URL

http://databank.worldbank.org/data/views/variableselection/selectvariables. aspx? source=GlobalEconomic-Monitor-(GEM)-Commodities (accessed 9.21.14) 
Figure 2. Brazil and US ethanol exports by destination

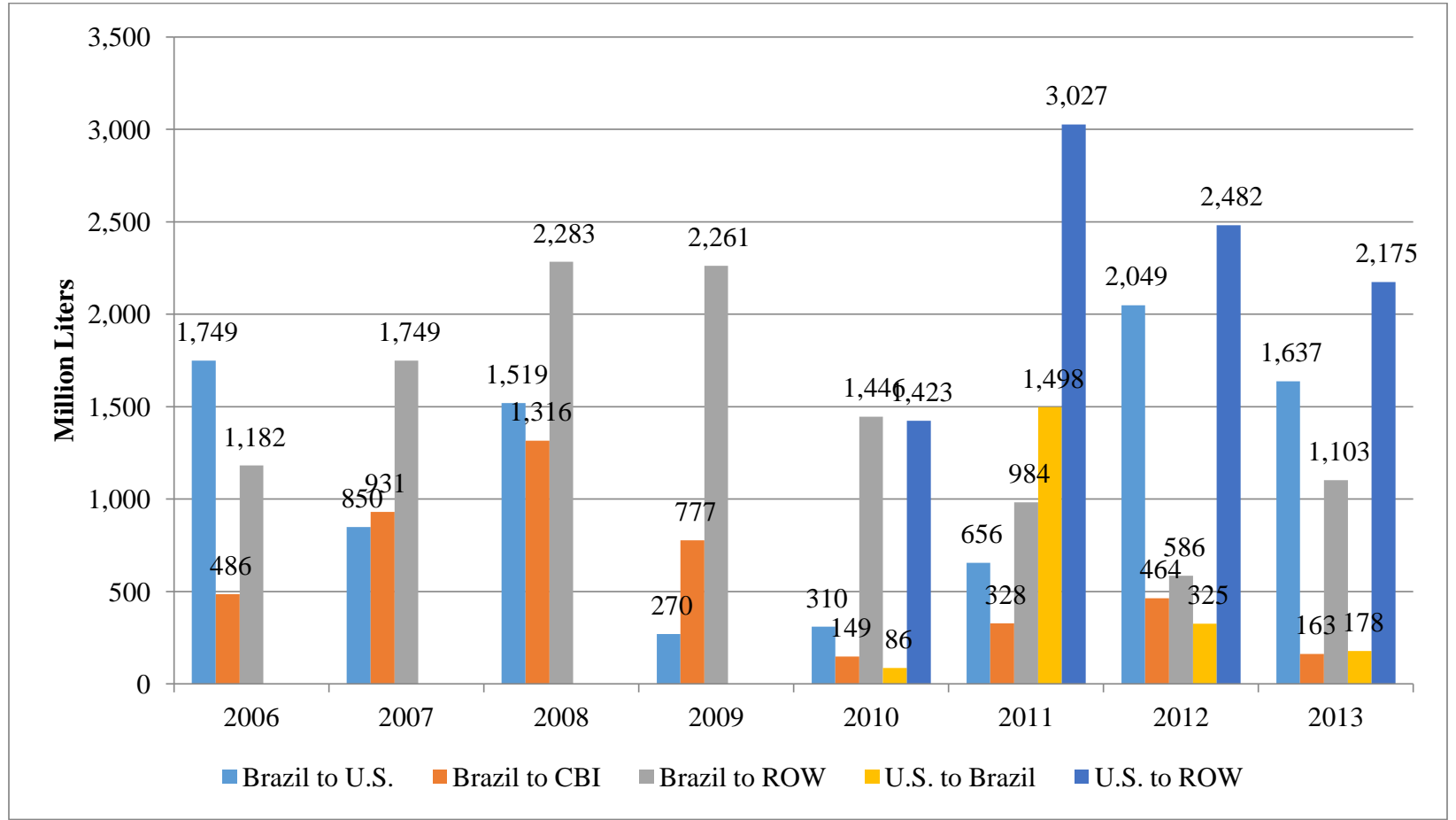

Source: EIA (2013) and UNICA (2013)

EIA. (2013). Independent Statistics \& Analysis [WWW Document]. URL http://www.eia.gov/petroleum/data.cfm (accessed 5.15.14)

UNICA. (2013). Dados e Cotações - Estatísticas. Uniao da Industria de Cana de Acucar [WWW Document]. URL from http://www.unica.com.br/dadosCotacao/estatistica/ (accessed 7.20.14) 
Figure 3. Brazil and international wholesale gasoline prices and Brazil hydrous ethanol price*, Jan. 2005 to Feb. 2014

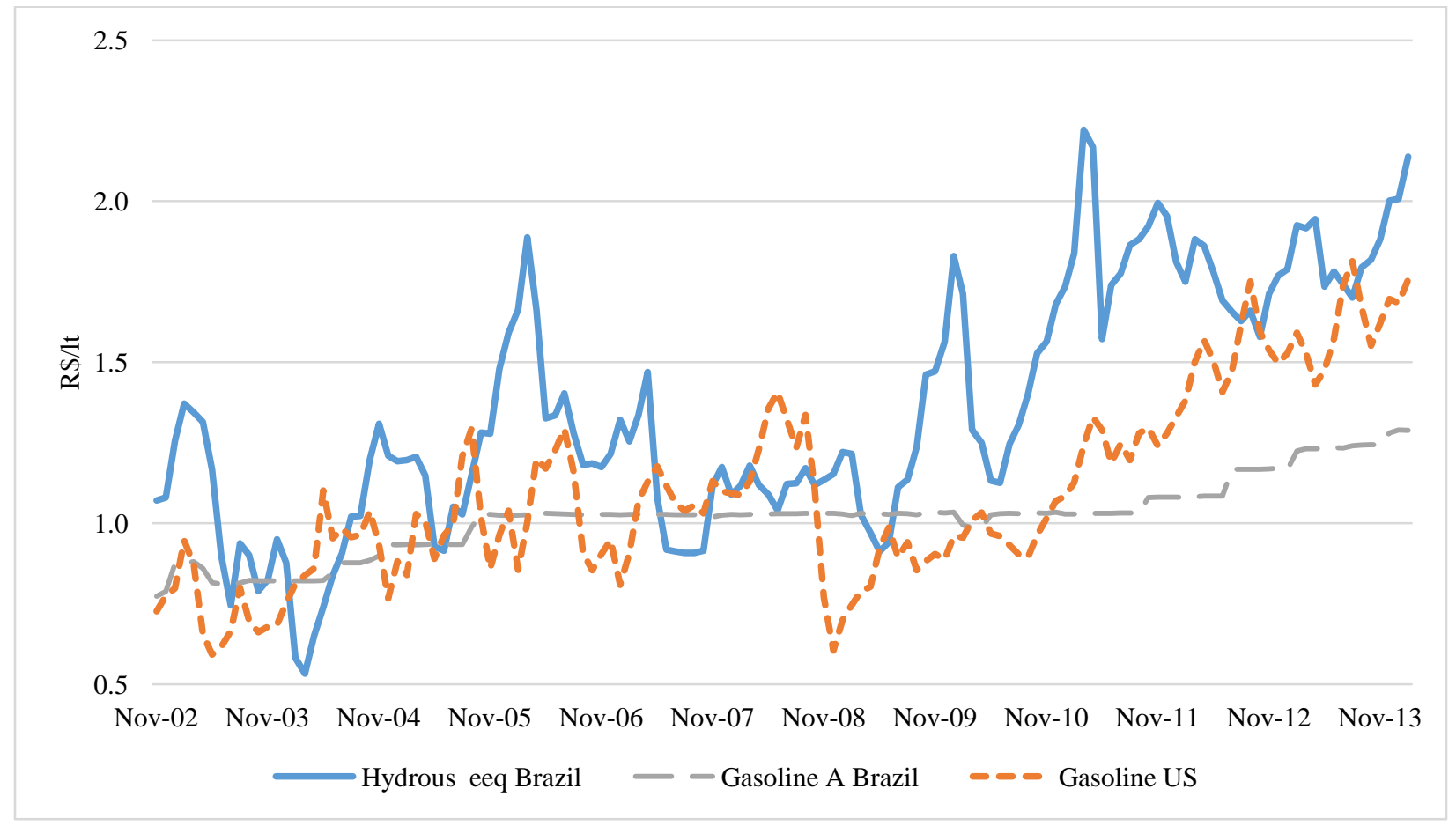

Source: EIA (2013), ANP (2013) and CEPEA/ESALQ/USP (2013). International prices were transformed from US Dollars to Brazilian Reais ( $\mathrm{R} \$)$. *Hydrous price is expressed in gasoline energy equivalents (eeq).

ANP. (2013). Preços de produtores e importadores de derivados de petróleo. Agência Nacional do Petróleo, Gás Natural e Biocombustíveis [WWW Document]. URL http://www.anp.gov.br/ (accessed 3.19.14)

CEPEA/ESALQ/USP. (2013). Indicadores de Preços [WWW Document]. URL from http://cepea.esalq.usp.br/indicador/ (accessed 3.19.14)

EIA. (2013). Independent Statistics \& Analysis [WWW Document]. URL http://www.eia.gov/petroleum/data.cfm (accessed 3.19.14) 
Figure 4. World fuel ethanol production trends, 1975-2013

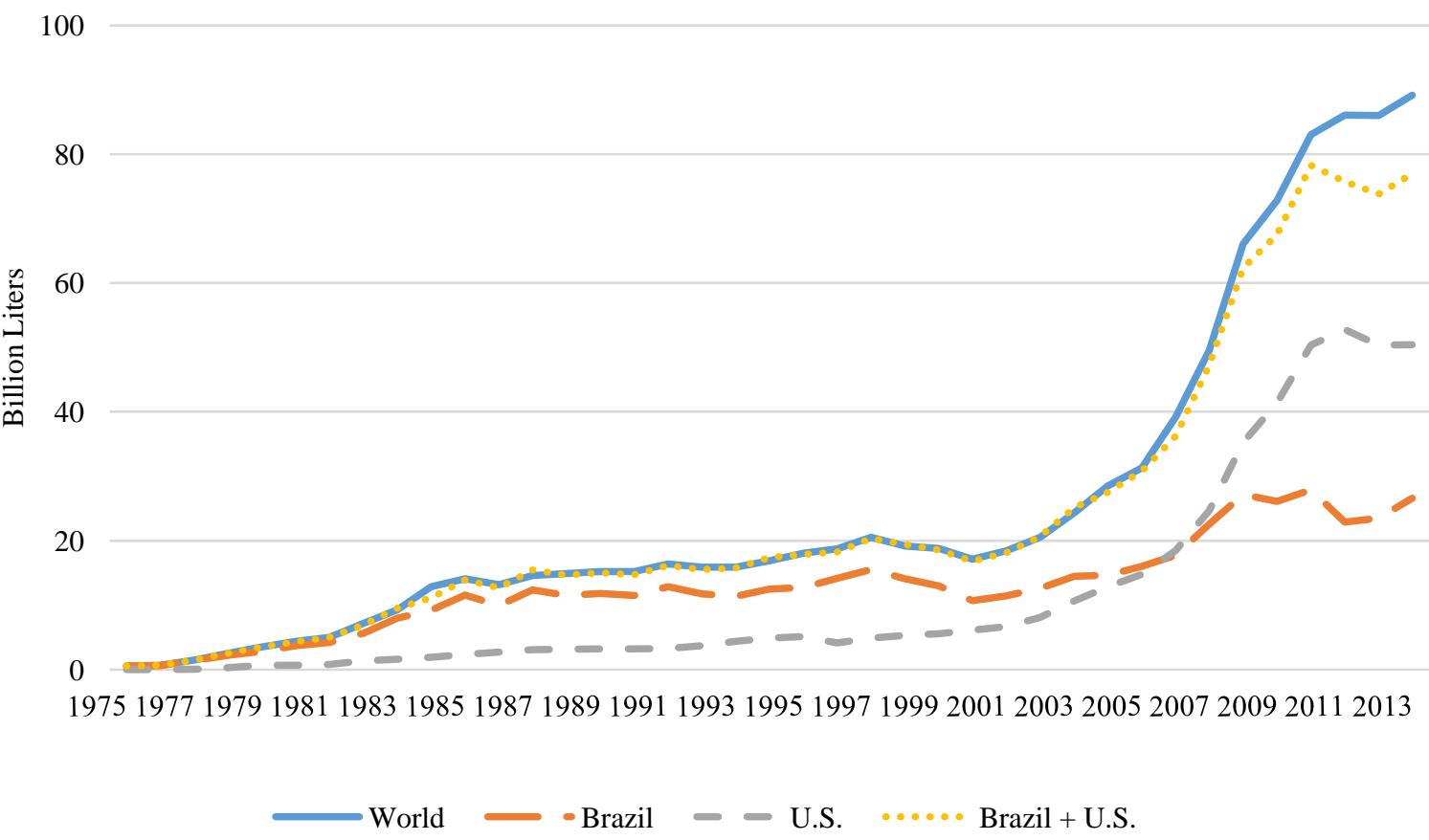

Source: EPE (2012), Earth Policy Institute (2012) and RFA (2012)

Empresa de Pesquisa Energetica, 2013. Balanço Energético Nacional [WWW Document]. URL https://ben.epe.gov.br/ (accessed 4.13.14).

Earth Policy Institute. (2012). Data Center [WWW Document]. URL http://www.earthpolicy.org/data_center/C23 (accessed 4.13.14).

RFA. (2012). Renewable Fuels Association Industry Statistics [WWW Document]. URL http://www.ethanolrfa.org/pages/statistics (accessed 4.13.14). 
Figure 5. Total Vehicle Kilometers Traveled (simulated, 2022)

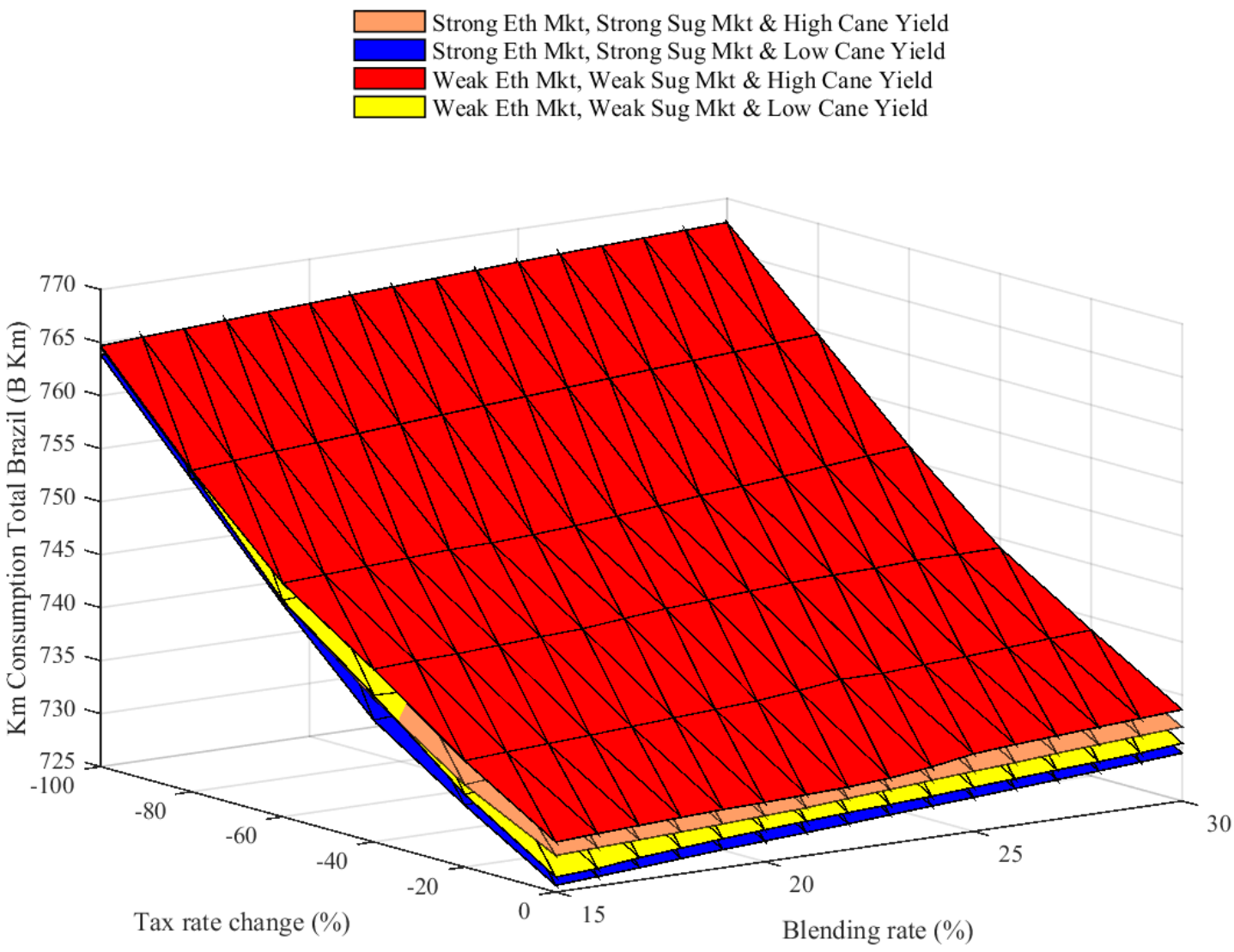


Figure 6. E100 price (simulated, 2022)

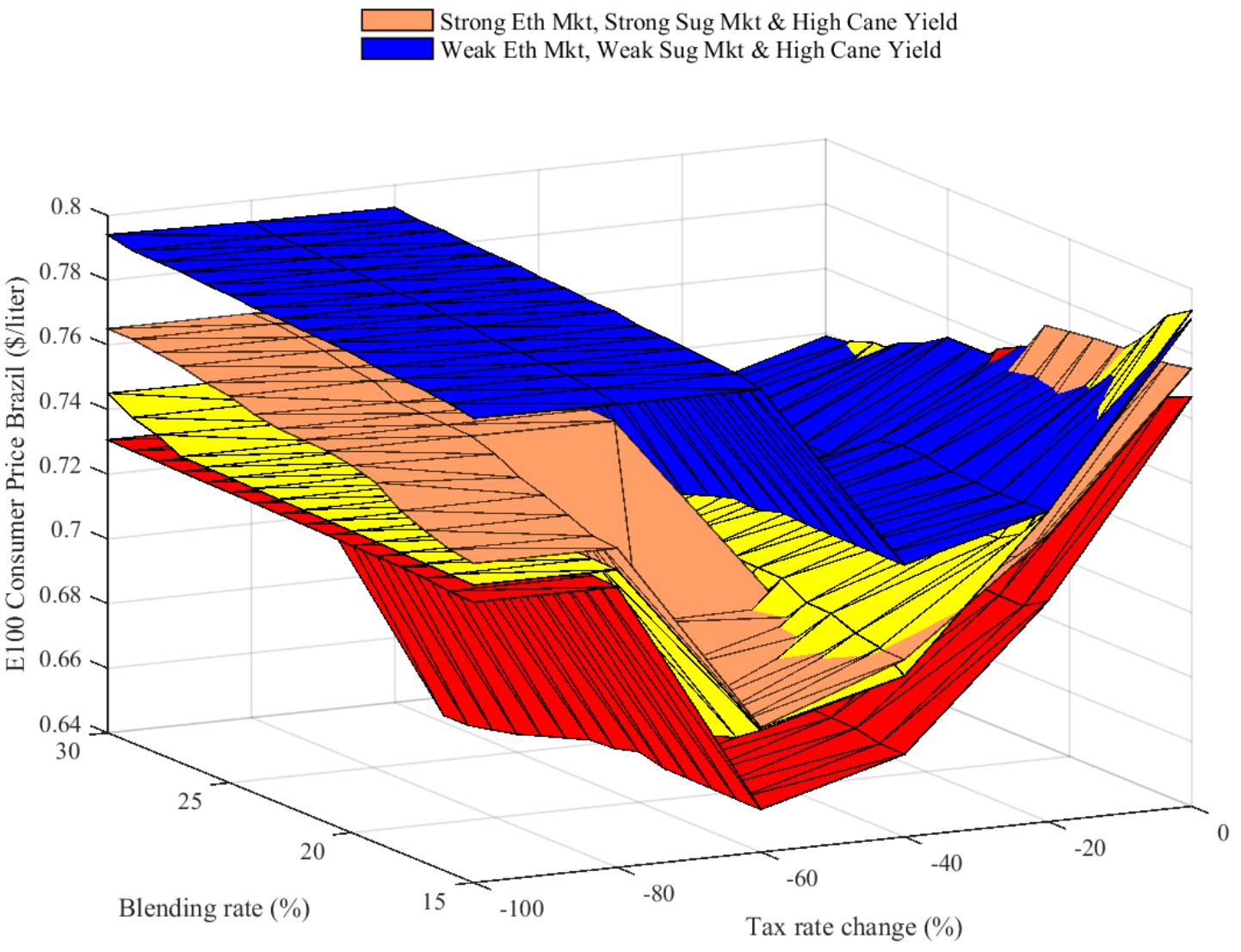


Figure 7. Direct lifecycle GHG emissions (CO2e) in Brazil (simulated, 2022).

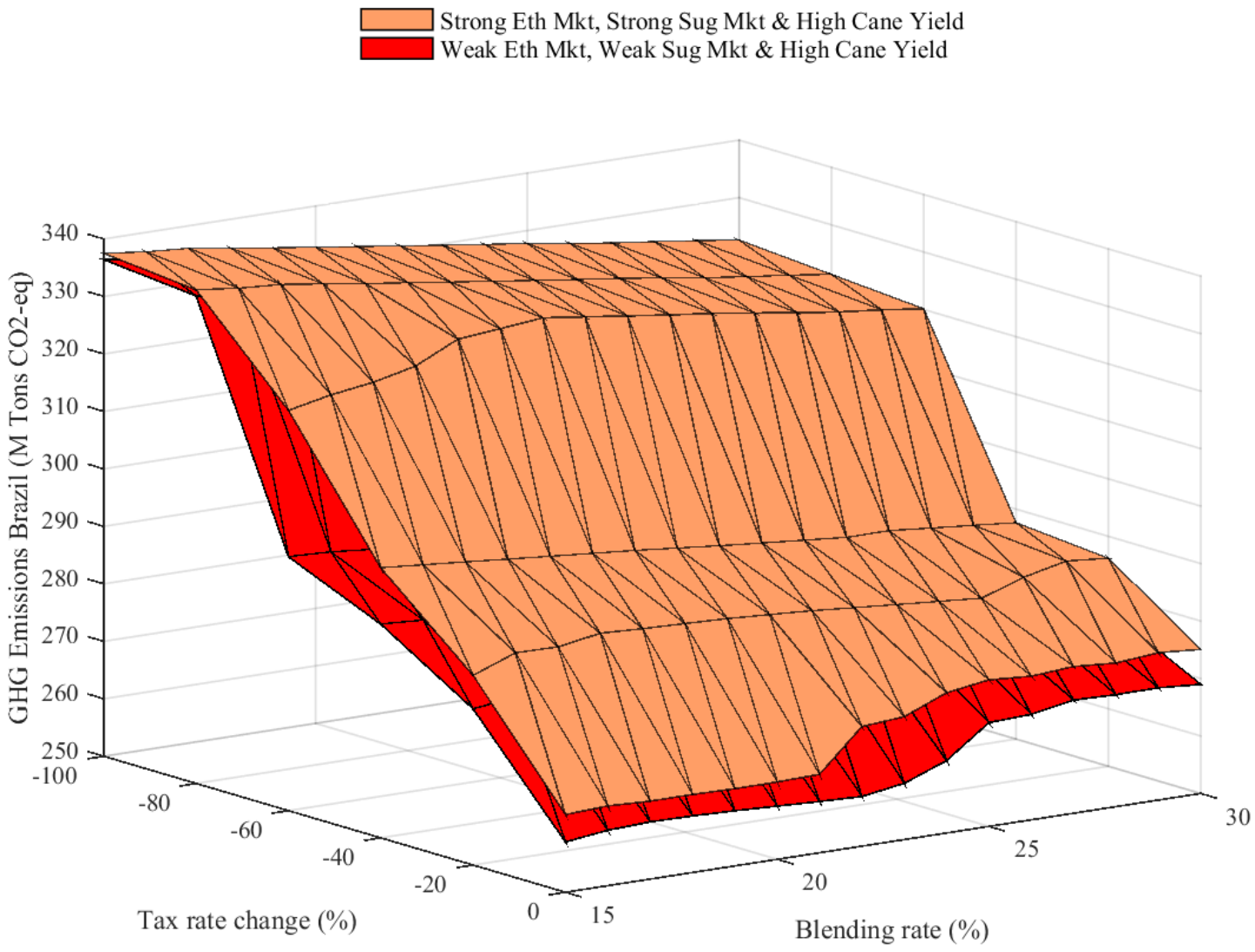

Note: For convenience of interpretation, the scenarios under the low cane yield scenario are not shown in this figure. Under the low cane yield scenario, the corresponding sheet for the strong sugar and strong ethanol world demand is similar to the copper sheet; the sheet for the weak sugar and weak world ethanol demand almost overlaps the red sheet. 
Figure 8. Ethanol producers' economic surplus (simulated, 2022)

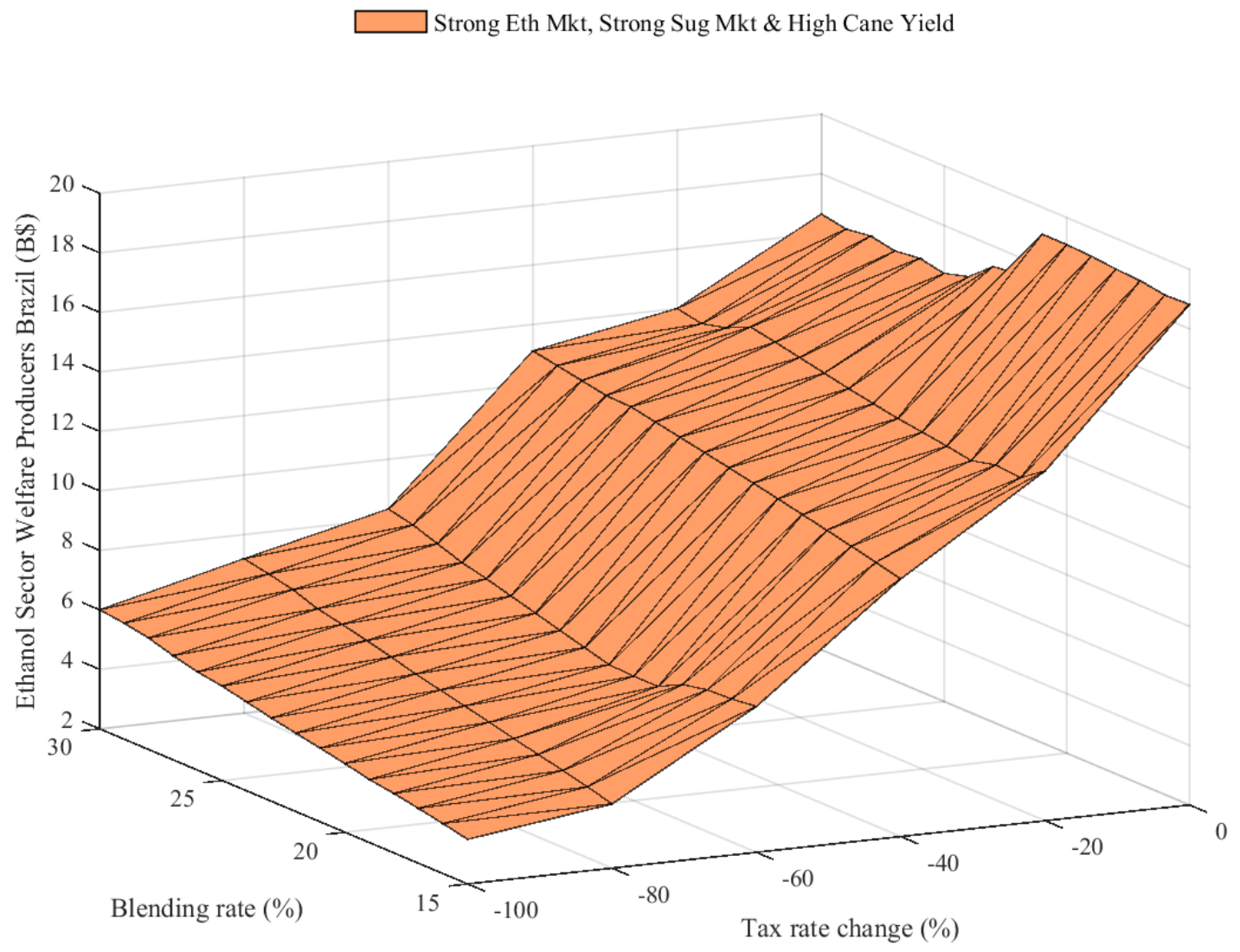

Note: For convenience of interpretation, the results for the other three scenarios are not shown in this figure. The corresponding sheets are very similar to the one shown here. 
Figure 9. Government fuel tax revenue (simulated, 2022)

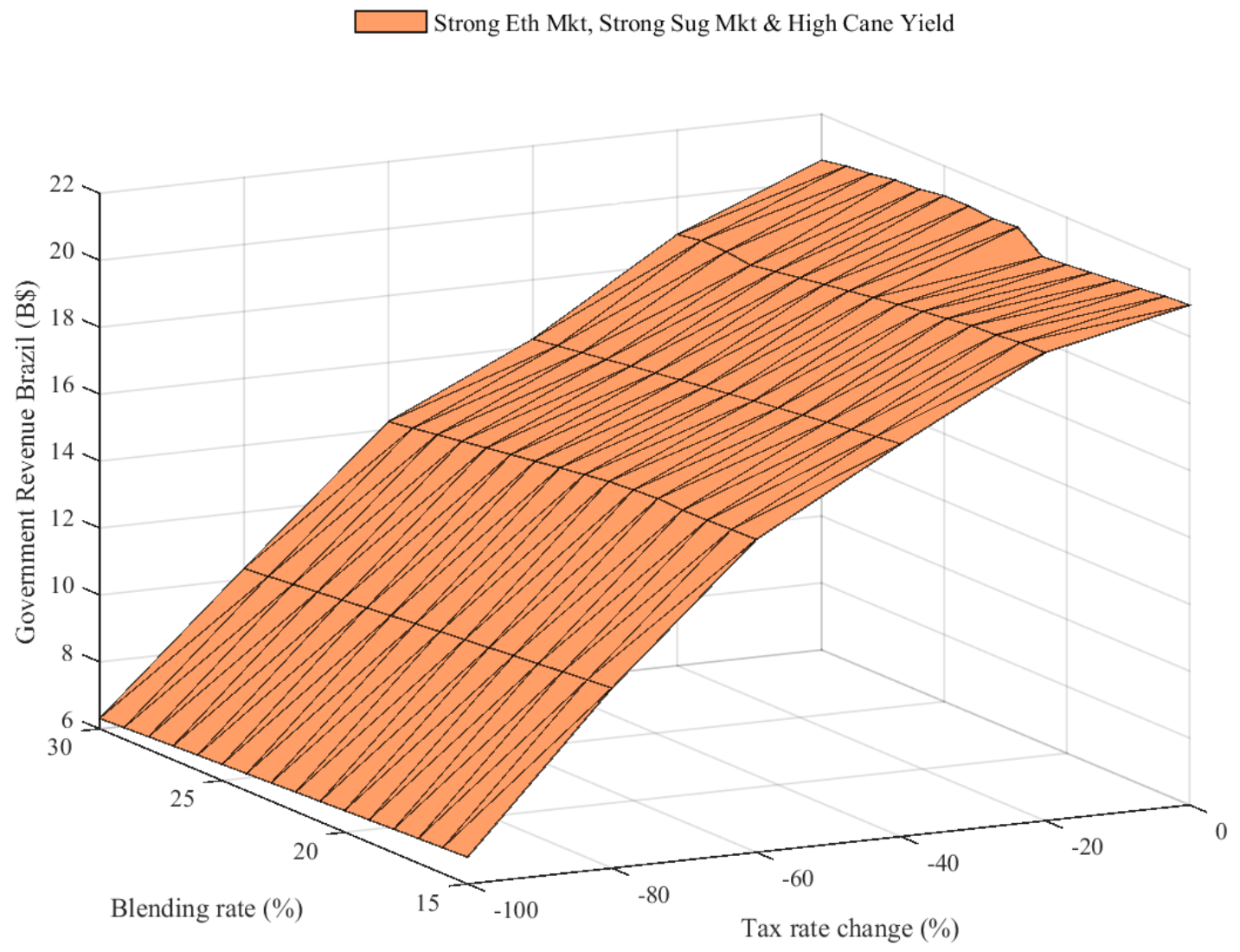

Note: For convenience of interpretation, the results for the other three scenarios are not shown in this figure. The corresponding sheets are very similar to the one shown here. 
Figure 1. World sugar market trends, 1984-2014

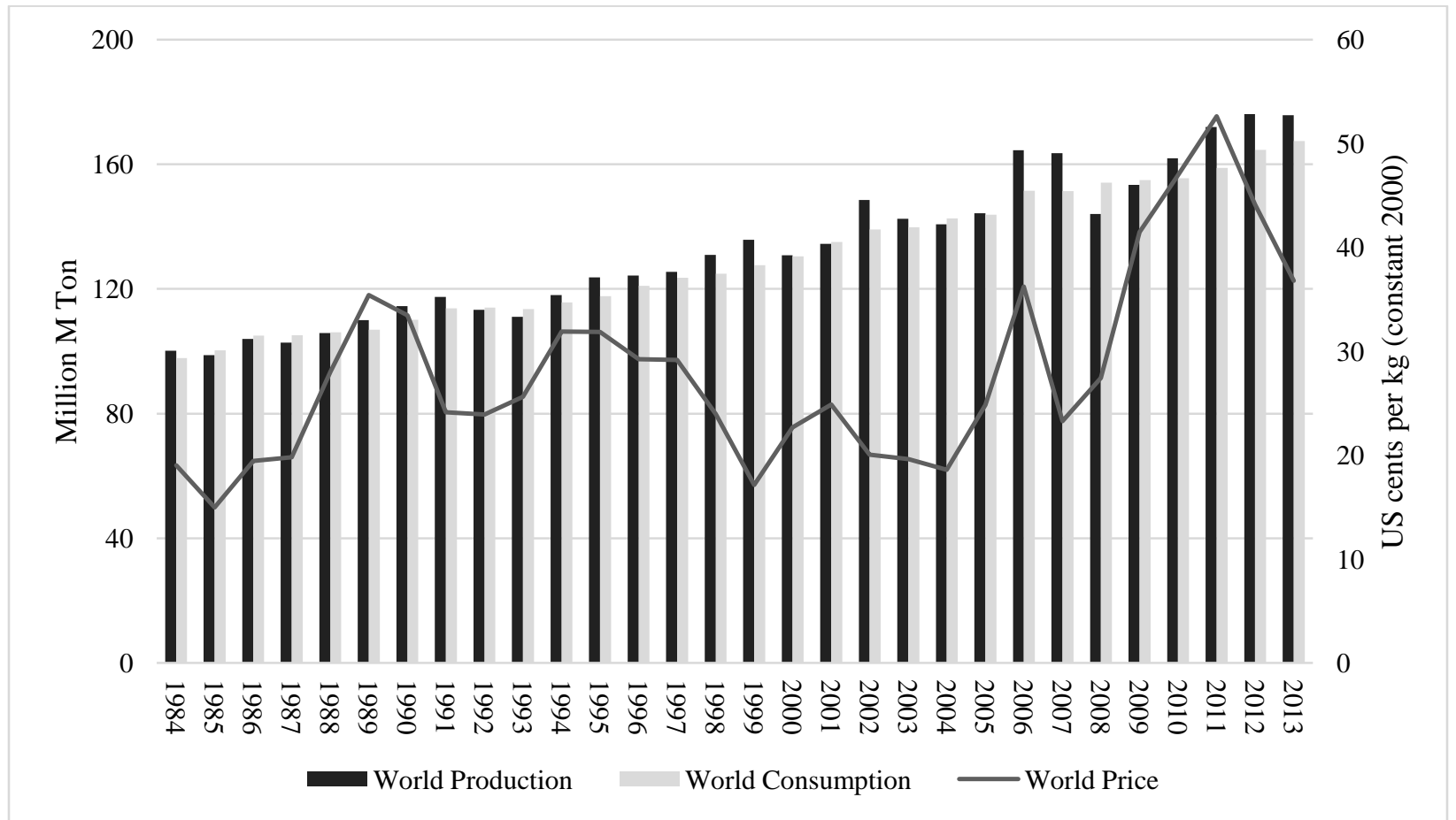

Source: USDA-FAS (2014) and World-Bank (2014)

USDA-FAS. (2014). Production, Supply and Distribution online. PSD [WWW Document]. URL http://www.fas.usda.gov/psdonline/psdQuery.aspx (accessed 9.21.14)

World-Bank (2014). World DataBank. Global Economic Monitor (GEM) Commodities PSD [WWW Document]. URL

http://databank.worldbank.org/data/views/variableselection/selectvariables. aspx?source=GlobalEconomic-Monitor-(GEM)-Commodities (accessed 9.21.14) 
Figure 2. Brazil and US ethanol exports by destination

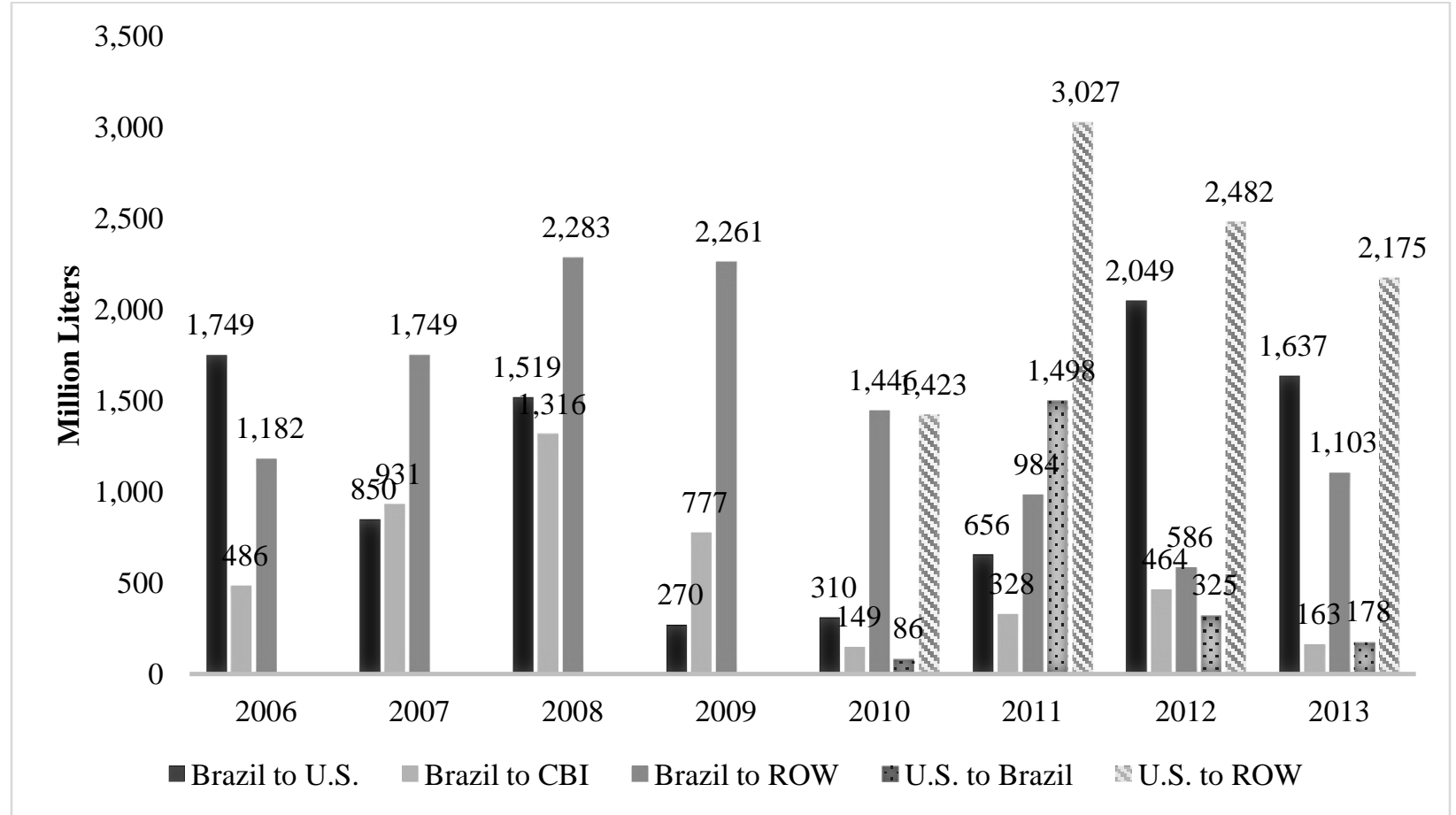

Source: EIA (2013) and UNICA (2013)

EIA. (2013). Independent Statistics \& Analysis [WWW Document]. URL http://www.eia.gov/petroleum/data.cfm (accessed 5.15.14)

UNICA. (2013). Dados e Cotações - Estatísticas. Uniao da Industria de Cana de Acucar [WWW Document]. URL from http://www.unica.com.br/dadosCotacao/estatistica/ (accessed 7.20.14) 
Figure 3. Brazil and international wholesale gasoline prices and Brazil hydrous ethanol price*, Jan. 2005 to Feb. 2014

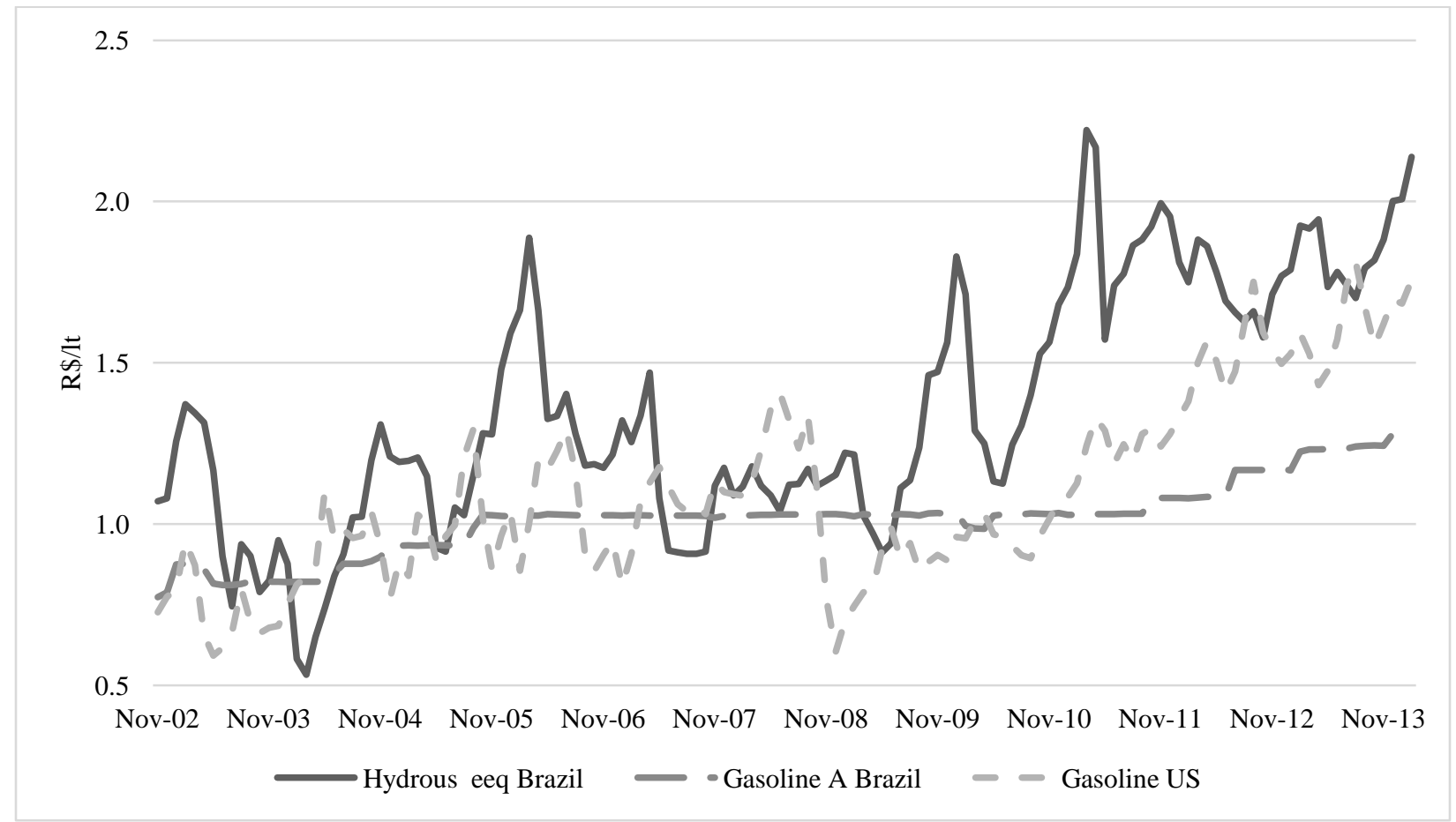

Source: EIA (2013), ANP (2013) and CEPEA/ESALQ/USP (2013). International prices were transformed from US Dollars to Brazilian Reais ( $\mathrm{R} \$)$. *Hydrous price is expressed in gasoline energy equivalents (eeq).

ANP. (2013). Preços de produtores e importadores de derivados de petróleo. Agência Nacional do Petróleo, Gás Natural e Biocombustíveis [WWW Document]. URL http://www.anp.gov.br/ (accessed 3.19.14)

CEPEA/ESALQ/USP. (2013). Indicadores de Preços [WWW Document]. URL from http://cepea.esalq.usp.br/indicador/ (accessed 3.19.14)

EIA. (2013). Independent Statistics \& Analysis [WWW Document]. URL http://www.eia.gov/petroleum/data.cfm (accessed 3.19.14) 
Figure 4. World fuel ethanol production trends, 1975-2013

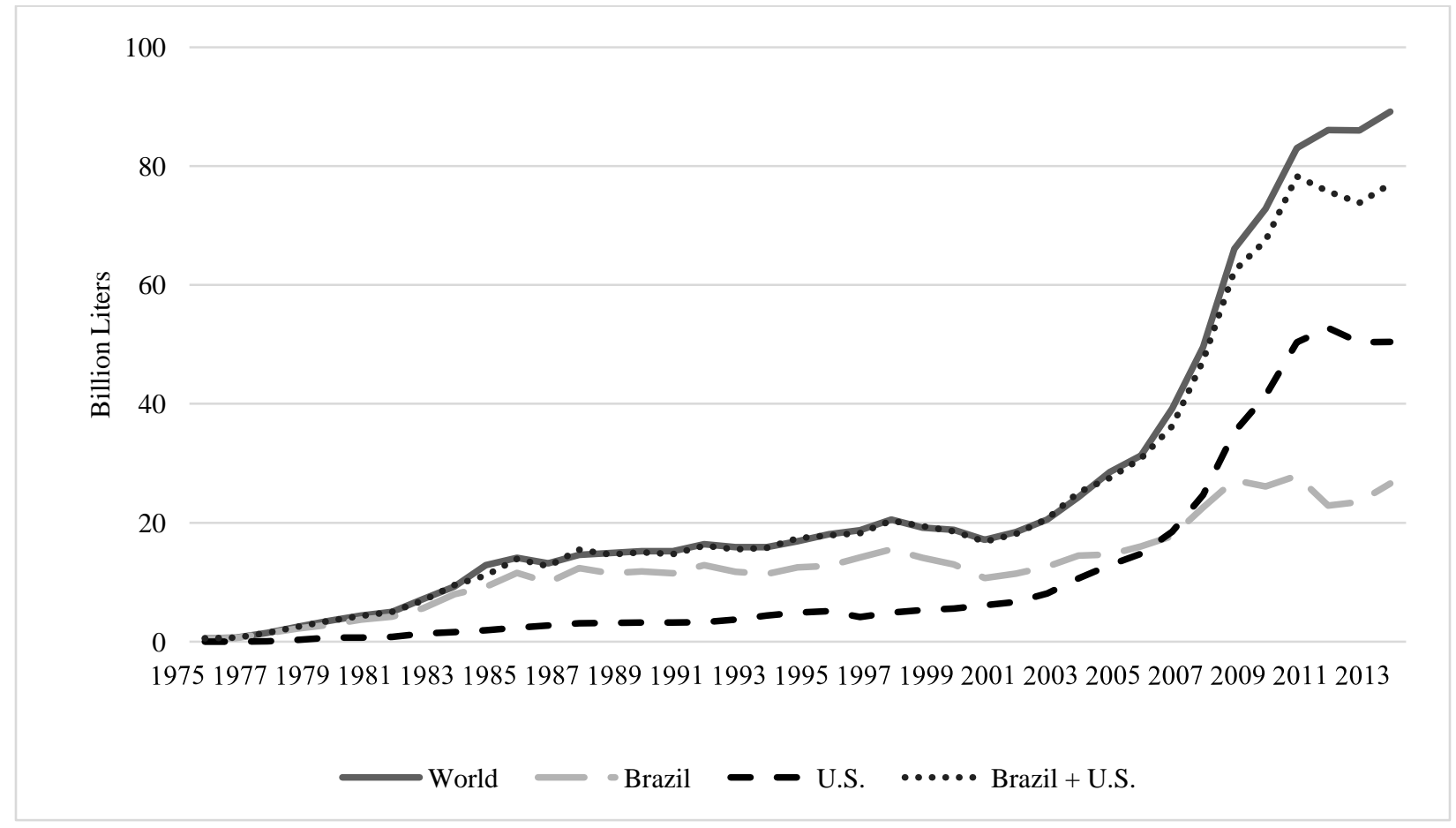

Source: EPE (2012), Earth Policy Institute (2012) and RFA (2012)

Empresa de Pesquisa Energetica, 2013. Balanço Energético Nacional [WWW Document]. URL https://ben.epe.gov.br/ (accessed 4.13.14).

Earth Policy Institute. (2012). Data Center [WWW Document]. URL http://www.earthpolicy.org/data_center/C23 (accessed 4.13.14).

RFA. (2012). Renewable Fuels Association Industry Statistics [WWW Document]. URL http://www.ethanolrfa.org/pages/statistics (accessed 4.13.14). 
Figure 5. Total Vehicle Kilometers Traveled (simulated, 2022)

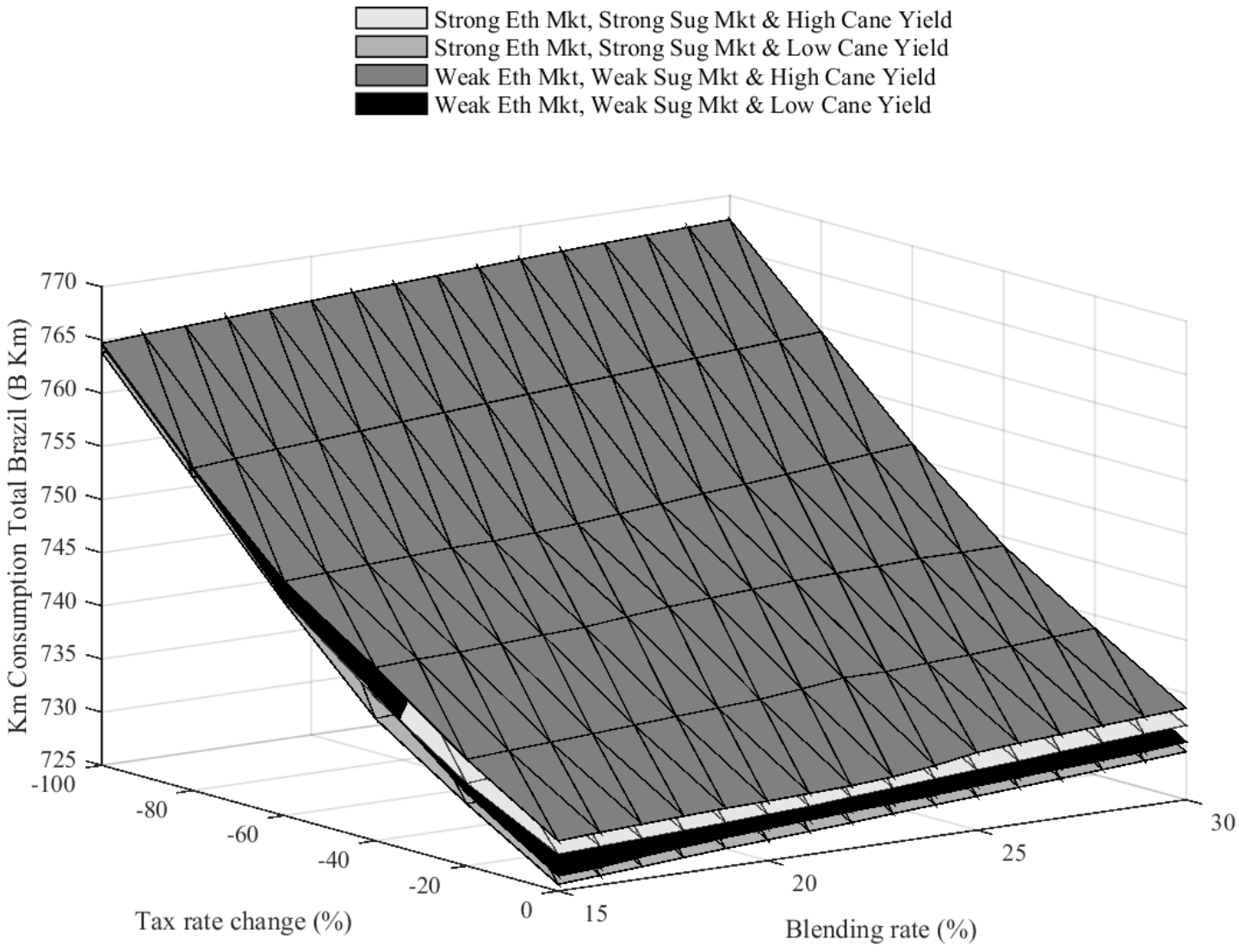


Figure 6. E100 price (simulated, 2022)
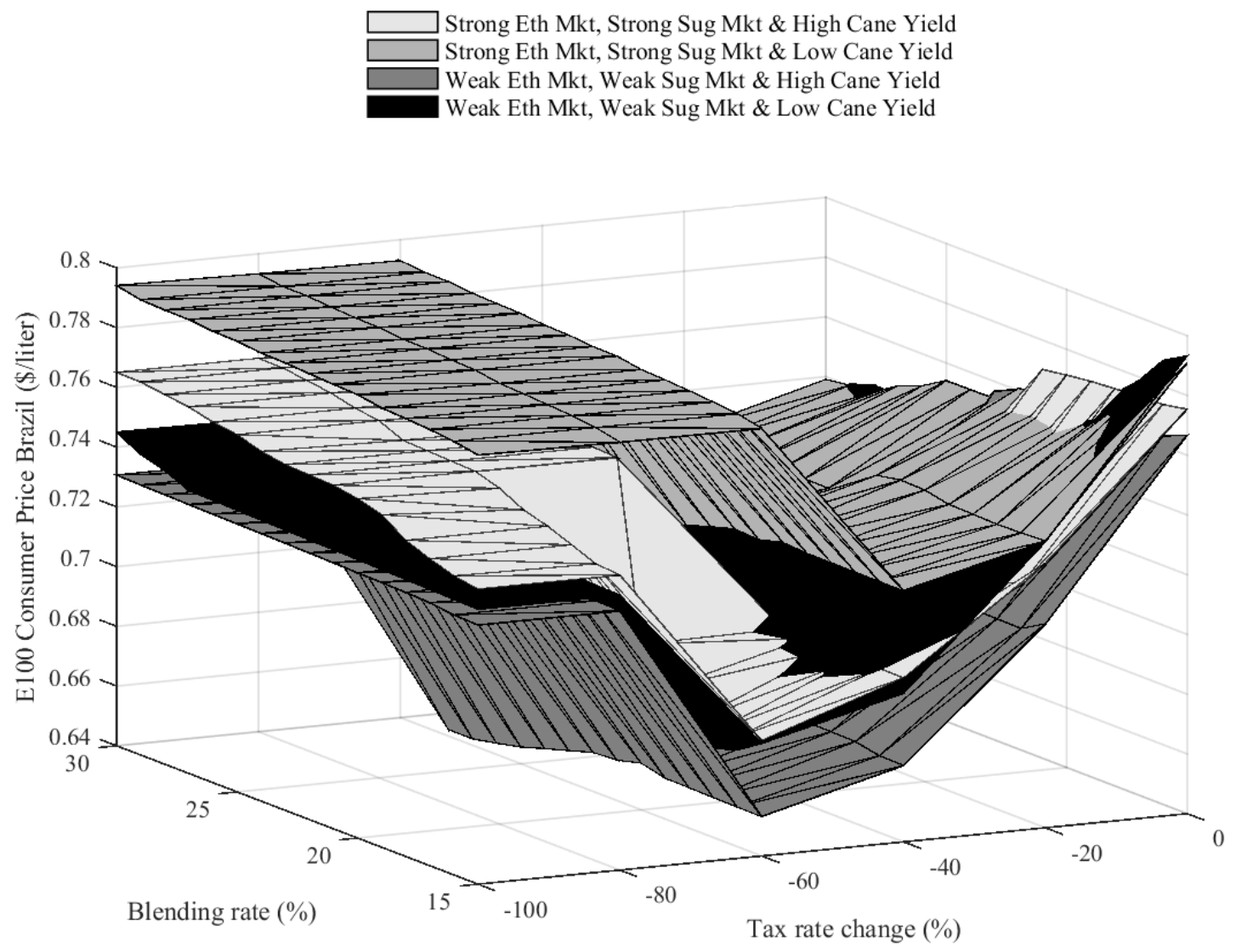
Figure 7. Direct lifecycle GHG emissions (CO2e) in Brazil (simulated, 2022).

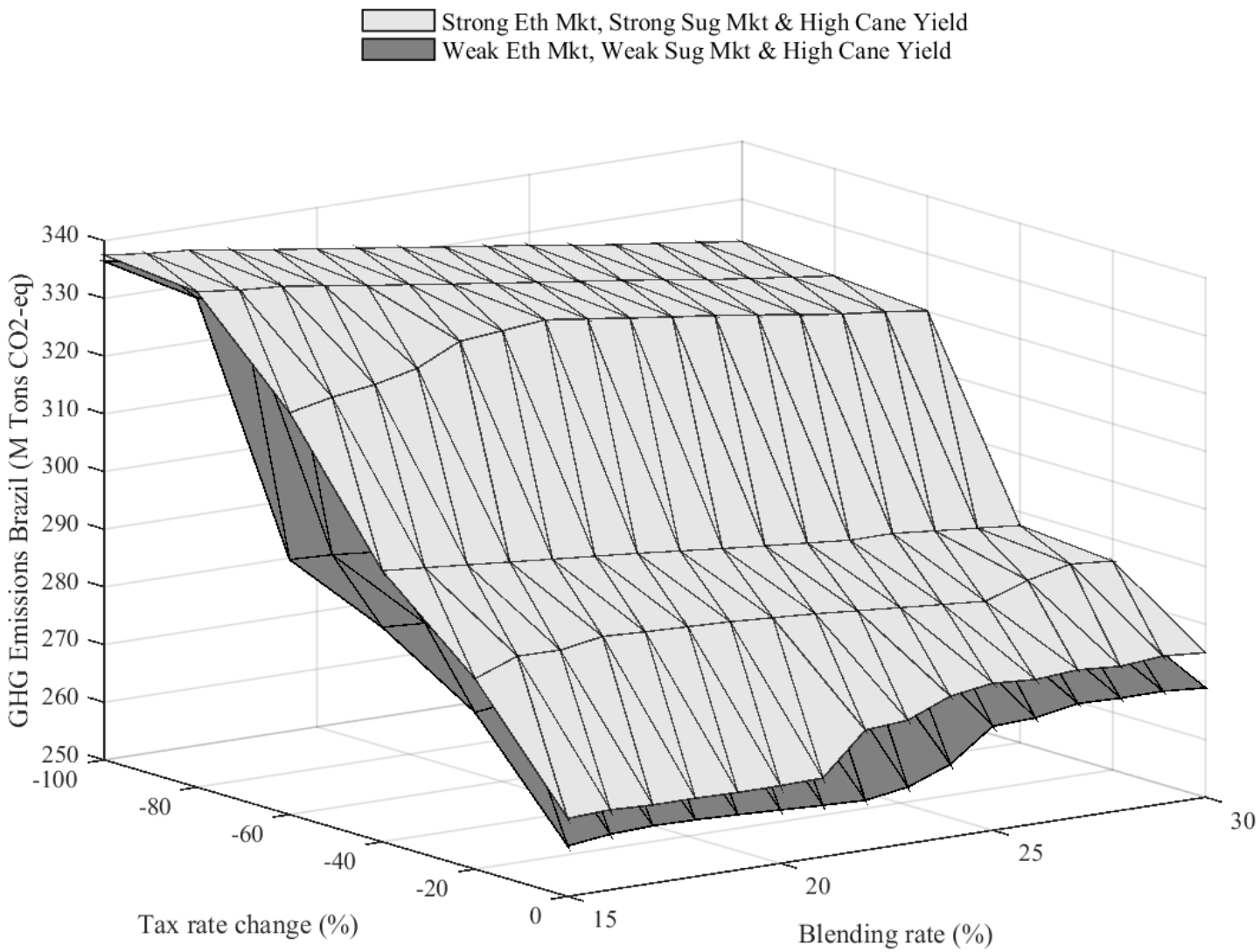

Note: For convenience of interpretation, the scenarios under the low cane yield scenario are not shown in this figure. Under the low cane yield scenario, the corresponding sheet for the strong sugar and strong ethanol world demand is similar to the copper sheet; the sheet for the weak sugar and weak world ethanol demand almost overlaps the red sheet. 
Figure 8. Ethanol producers' economic surplus (simulated, 2022)

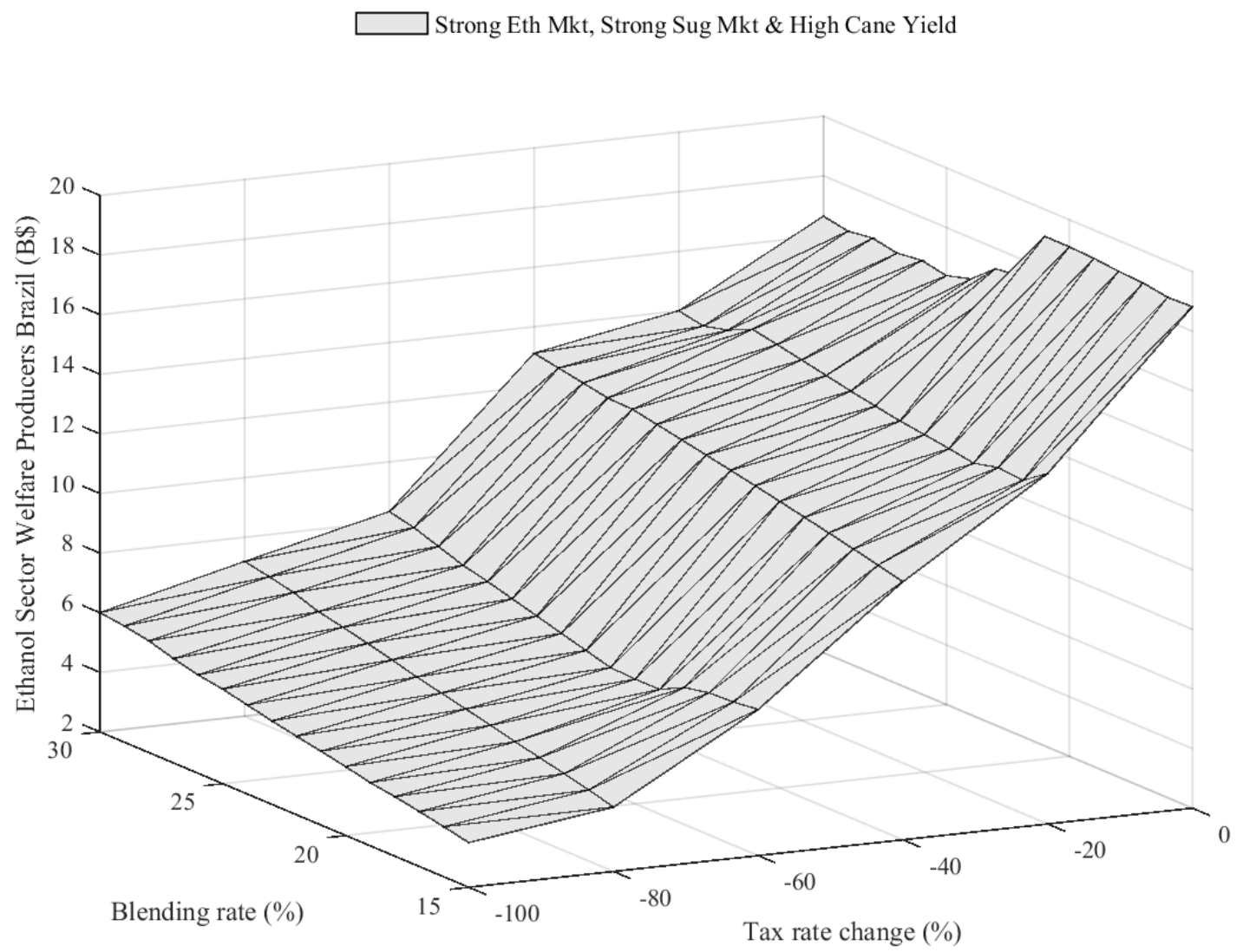

Note: For convenience of interpretation, the results for the other three scenarios are not shown in this figure. The corresponding sheets are very similar to the one shown here. 
Figure 9. Government fuel tax revenue (simulated, 2022)

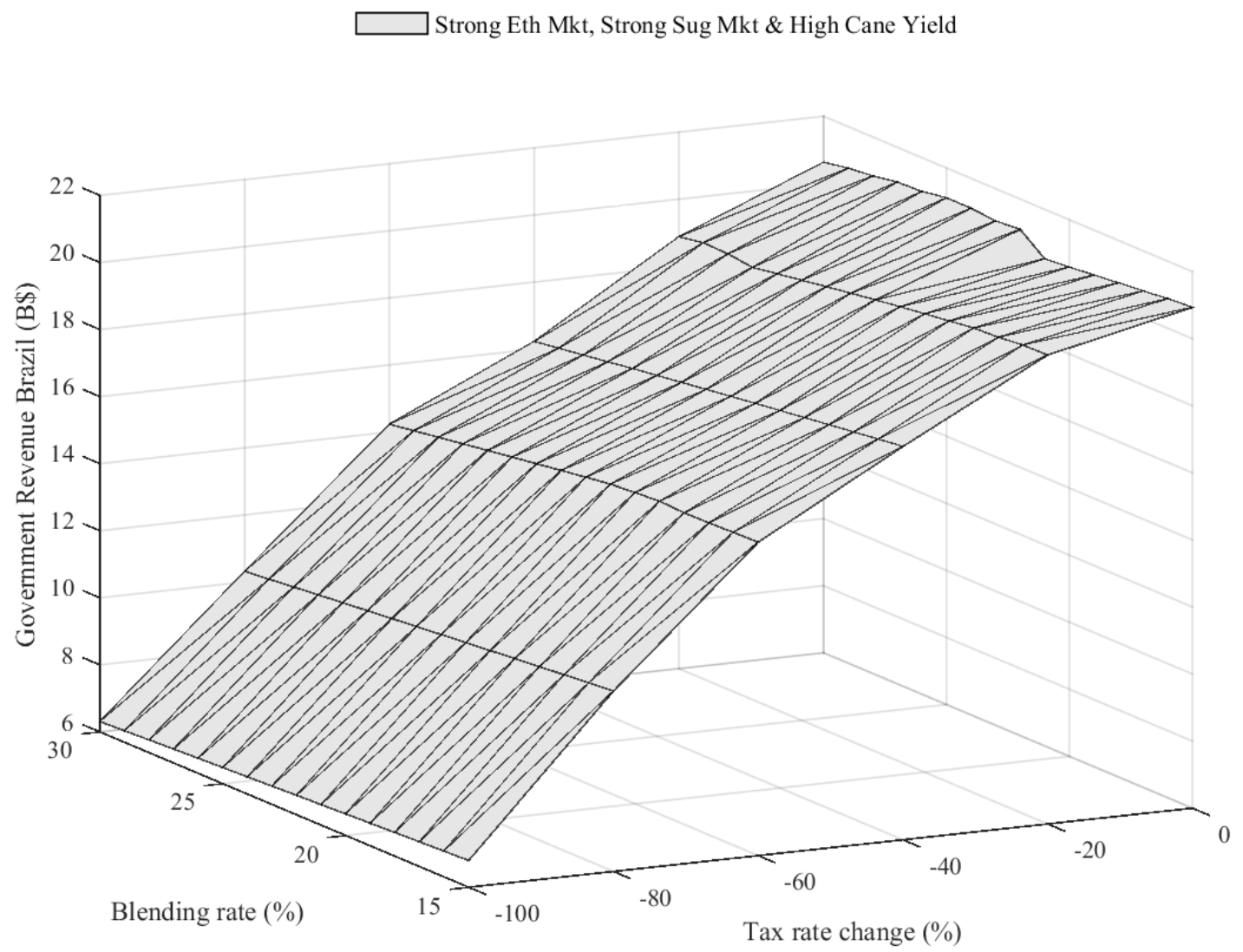

Note: For convenience of interpretation, the results for the other three scenarios are not shown in this figure. The corresponding sheets are very similar to the one shown here. 